Review article

\title{
LOOKING FOR THE CAUSES OF AND SOLUTIONS TO THE ISSUE OF HONEY BEE COLONY LOSSES
}

\author{
STANIMIROVIĆ Zoran ${ }^{1}$, GLAVINIĆ Uroš ${ }^{*}$, RISTANIĆ Marko $^{1}$, \\ ALEKSIĆ Nevenka², JOVANOVIĆ Nemanja ${ }^{1}$, VEJNOVIĆ Branislav ${ }^{3}$, \\ STEVANOVIĆ Jevrosima ${ }^{1}$
}

\begin{abstract}
${ }^{1}$ Department of Biology, Faculty of Veterinary Medicine, University of Belgrade, Bul. Oslobodjenja 18, Belgrade, Serbia; ${ }^{2}$ Department of Parasitology, Faculty of Veterinary Medicine, University of Belgrade, Bul. Oslobodjenja 18, Belgrade, Serbia; ${ }^{3}$ Department of Economics and Statistics, Faculty of Veterinary Medicine, University of Belgrade, Bul. Oslobodjenja 18, Belgrade, Serbia
\end{abstract}

(Received 19 February, Accepted 28 February 2019)

Colony losses, including those induced by the colony collapse disorder, are an urgent problem of contemporary apiculture which has been capturing the attention of both apiculturists and the research community. CCD is characterized by the absence of adult dead bees in the hive in which few workers and a queen remain, the ratio between the brood quantity and the number of workers is heavily disturbed in favor of the former, and more than enough food is present. Robbing behavior and pests usually attacking the weakened colony do not occur. In the present paper, the causes of the emergence of this problem are discussed, as well as the measures of its prevention.

The following factors, which lead to colony losses, are analyzed: shortage of high-quality food (pollen and honey); infestation with parasites, primarily with Varroa destructor, and mixed virus infections; bacterial infections (American and European foulbrood), fungal infections (nosemosis and ascosphaerosis) and trypanosomal infections (lotmariosis); and, finally, general management of the apiary.

Certain preventive measures are proposed: (1) providing ample high-quality forage and clean water, (2) avoiding sugarisation, i.e. superfluous use of sugar syrup, (3) meeting the nutritional needs of the colony, (4) when feeding bees, taking care of the timing and the composition of diet, avoiding pure sugar syrup which in excessive quantities may induce energetic and oxidative stress, (5) when there is a shortage of natural feed - honey in the brood chamber - use sugar syrup with natural/artificial supplements to avoid protein starvation, (6) organized control of $V$. destructor in the colonies is obligatory due to its vector role, and (7) compliance with hygienic and sanitary measures and principles of good apiculture practice and management in apiaries. To conclude, all preventive measures are feasible in compliance with rules and regulations concerning regular spring and autumn bee health monitoring by licensed veterinarians, who can propose adequate treatments if necessary.

Key words: Apis mellifera, colony losses, honey bee pathogens, nutrition, pesticides

\footnotetext{
*Corresponding author: e-mail: uglavinic@vet.bg.ac.rs
} 


\section{INTRODUCTION}

Given their contribution to pollination, managed honey bees (Apis mellifera) are far more respected for this activity than for the production of honey and other products $[1,2]$. Thus, it is understandable that substantial losses of bee colonies in the United States and Europe keep startling beekeepers and scientists, especially because there is no agreement on the definite cause(s) of this syndrome. Extensive research has shown that no single factor can be accused of the losses, which lead to seemingly the only possible conclusion that multiple stressors must be involved, such as loss of forage, pathogens, parasites, agropesticides and incorrect beekeeping practices [3-10]. Thus, it is very hard to propose a single solution which could be most effective [11]. Historical data prove that there were huge losses in the past, although they did not generate such avid interest. Even though tremendous losses do exist throughout the world, their causes vary with time and place. Many international attempts at understanding the causes and occurrence of bee losses were made. Recently, two independent groups of scientists conducted extensive studies. A two-year monitoring of nearly 6,000 apiaries in 17 European countries revealed that winter losses, ranging widely from $2 \%$ to $32 \%$, were frequently followed by seasonal losses [12]; the COLOSS questionnaire filled out by 14,813 beekeepers from 27 European countries, Algeria, Israel and Mexico revealed that in winter $2016 / 2017$ out of 425,762 colonies, $5.1 \%$ suffered unsolvable queen problems and $14.1 \%$ failed to survive the winter [13]. Natural disasters killed another $1.6 \%$ of honey bee colonies, which added to a total of $20.9 \%$ colony losses. The losses varied between countries and were considerably higher in apiaries owned by beekeepers who had small numbers of colonies. Analysis detected that migratory beekeeping did not affect significantly the winter loss, but had some influence in several countries [13].

Because of the multifactorial nature of colony losses, it is extremely complicated to conduct controlled reproducible research on the influence of factors involved [6]. Despite the steep decrease in the numbers of managed bee colonies in Europe $(25 \%$ in central Europe from 1985 to 2005) and in North America (59\% from 1947 to 2005), globally there was a significant rise in their number by approximately 45\% (19612008), owing to the enormous increase in China and Argentina, for instance [6]. Thus, it was suggested that colony losses should be considered throughout the year, rather than taking into account those happening in winter only.

Colony losses in general should not be equated with a specific phenomenon known as colony collapse disorder - CCD [7], that was introduced and described by van Engelsdorp et al. [14] as a condition manifested in sudden bee death and the absence of adult dead bees, both inside and in front of the hive. Most frequently, there is a queen and few (a handful) workers which have survived. There is a huge quantity of brood, which is disproportional to the number of worker bees. There are ample food reserves (honey and bee bread). It is also characteristic that in the hives robbing behavior and invasion by common pests (wax moths and small hive beetle) appear much later [11, 14-16]. 
In compliance with the European Food Safety Authority - EFSA [17], the most frequent causes of colony losses are:

- Shortage of high-quality food (pollen and honey),

- Parasitic infestations, primarily by Varroa destructor and mixed virus infections,

- Bacterial infections (American and European foulbrood), fungal (nosemosis and ascosphaerosis) and other infections,

- General management in the apiary.

\section{Shortage of high-quality food}

Global climate changes, environmental pollution and "chemisation" in all human activities, especially in agriculture, lead to disturbances in the ecosystem, plant production, and production of high-quality food intended for bees. Global changes in the flowering dynamics, and the quantity and quality of pollen and nectar [18], as well as the practice of growing monocultures (corn), which are of low quality for bees, additionally increase the risk of protein starvation in bees [19-21]. In the last several decades, the diversity of melliferous plant species changed globally, and in Serbia alone Stachys annua disappeared, and some others have drastically decreased nectar and pollen production, e.g. Trifolium repens, T. pratense, Melissa officinalis, Thymus serpyllum and Mentha piperita [22]. Moreover, intensive pesticide use decreases the production of pollen, which is transformed into quality bee bread, the main protein source for 3-18-day-old bees and older open brood [18, 22, 23]. Further, decline in the number of grazing animals (primarily sheep and goats), and, consequently, decreased manure production, leads to impoverished land, significantly lower reproduction of melliferous plants. Pollen quality changes throughout the season, the best being provided by early blooming plants: Corylus avellana, Salix alba and S. nigra, Helleborus odorus, Galanthus nivalis, Viola spp., Laminum spp., fruit trees, Taxacarum spp., Poaceae family etc.

Nevertheless, the number of hives has been on the increase, owing to the needs of people to contribute to their household income, which led to the overpopulation of certain areas with hives and shortage of food for bees [10]. In attempts to gain growth in earnings, beekeepers neglect the bees' needs: they deprive them of honey even from brood chamber, which belongs exclusively to the bees and is an ideally balanced, energy and protein-rich food, the most important factor for wintering and fast spring development of the brood and the colony as a whole. By mixing the honey from brood and honey chambers beekeepers harm both the bees and themselves. Thus, bees remain without the best energy and protein-rich food, which the beekeepers try to make up for by feeding the bees with sugar syrup. However, it provides only additional energy, influences negatively the development and survival of the colony, disturbs the structure of the winter cluster, leads to energy and oxidative stress and decline in the immune system, and intensifies pathogen development and reproduction $[14,18,20,24-31]$. This leads to the disturbance of temporal polyethism and absence or fewer sanitary bees (in-hive 12-18-day old bees), that is, to decreased hygienic, and 
grooming behavior [32-39]. Temporal polyethism is of utmost importance. Worker bees specialized in performing various tasks communicate closely, which provides colony survival, but also enables easier pathogen distribution in the colony (Figure 1). In addition, in inadequately fed bee colonies a decrease in the numbers of workers and drones, and lower vitality and resistance to pathogens (notably to N. ceranae) are often noticeable [40].

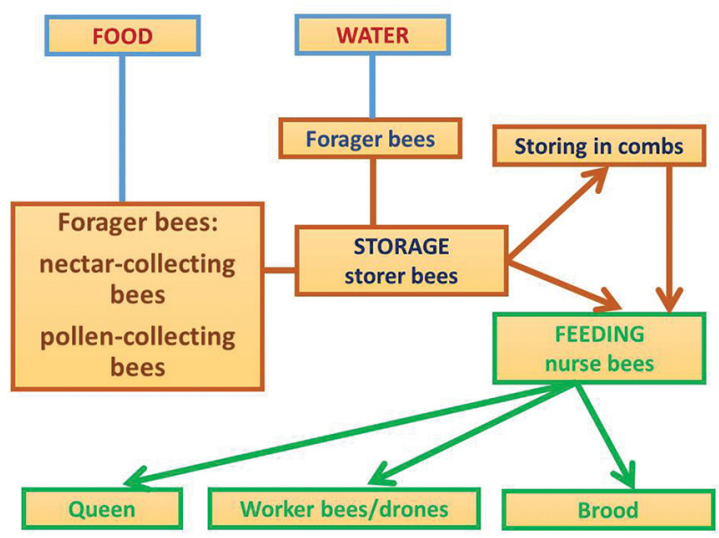

Figure 1. Flow of food and water in the honey bee colony and communication between different bee castes

Moreover, honey taken from brood chambers may contain residues of various preparations (amitraz, coumaphos, cymiazole hydrochloride, flumethrine, fluvalinate, dicyclohexylamine and fumagillin) which contaminate the honey directly (used in autumn and winter-spring treatments), or indirectly, from already contaminated wax. This honey is not eligible for human consumption because antibiotic and pesticide residues may exert various genotoxic effects [41-48].

\section{Infestation with Varroa destructor and mixed virus infections}

Varroa destructor, an obligate parasite of $A$. mellifera, poses the greatest threat to beekeeping. Due to the absence of an efficacious control programme, infested bee colonies collapse in a 2-to-3-year period [49]. Together with the associated bee viruses, the mite is one of the main causes of winter losses of bee colonies [7, 50-53]. Recently, it has been detected that Varroa feeds on the fat body of the larvae and adult bees [54], rather than exclusively on haemolymph, as previously considered [49, 55, 56]. Moreover, the reproductive performance was better in mites fed on fat body than in those which consumed haemolymph [54].

$V$. destructor harms the bees directly, by exhausting them due to the disturbances they make in their metabolic processes, notably that of proteins [57], and indirectly, acting as a vector and/or activator of bee viruses [52, 58-60]. The mite and the Deformed Wing Virus-DWV together produce the most deleterious effect on the bees, which 
leads to the reduction in their lifespan and have been one of the most common causes of colony losses across the globe over the past 50 years [55, 56, 61, 62]. Nevertheless, other viruses or their combination (Acute Bee Paralysis Virus - ABPV or AcuteKashmir-Israeli complex - AKI) may also cause colony losses together with Varroa mites as drivers that increase viral titers [51, 52, 63, 64].

Investigating into the mechanisms of synergistic actions between $V$. destructor and DWV, Nazzi et al. [62] proved that the mite is capable of destabilizing the dynamics of DWV development in the bees' body and lead to the transformation of the virus into a fast-replicating killer, which reaches lethal levels at the end of the season. The destabilization of a strong down-regulation of the transcription nuclear factor kappa $\mathrm{B}(\mathrm{NF}-\mathrm{kB})$ leads to immunosuppression [62] and the disturbance of various levels of immunity regulated by this factor, such as the synthesis of antimicrobial peptides, haemocyte aggregation at the sites of injuries, melanisation and antiviral mechanisms of defense [65]. It is considered that the immunosuppressive effect, primarily owing to viruses, increases the negative impact of the transcriptional profile of several immune genes in the bee. Moreover, in the absence of viruses, Varroa mites do not influence the expression of dorsal-1 $A$ gene, an indicator of immunosuppression, unlike DWV, which produced the largest decrease in the expression of this gene [62]. This immunosuppressive activity is explained as part of the strategy used by DWV to conquer the central components of the host's antiviral immunity, thus providing conditions for covert infection. However, any environmental stressor (e.g. pesticides or poor nutrition) may disturb the delicate, balanced relationship between the viral pathogens and the bees' defense mechanisms, leading to the activation of the response through NF-kB and intensive virus replication in bees in which the infection was covert until then. The most common final consequence of fast virus replication is the collapse of the bee colony $[61,62,66]$. Further investigation into the mechanisms of interaction in the mite-virus complex and the induction of honey bee colony losses revealed the existence of mutualistic symbiosis between Varroa parasites and DWV, which is aimed at defeating the immune barriers of the host [55].

Additional research into the bees' response to simultaneous Varroa infestation and DWV infection proved that honey bees are able to promptly produce high immune and homeostatic response, which does not last long and is followed by downregulation of these pathways, rendering the bees susceptible to extensive virus replication [56]. Fine et al. [67] reported that even inert substances in agrochemicals may also add to some negative effects on bees, including increased virus-induced mortality. Herbicides, although designed to inhibit weed growth, limit the availability of floral resources and adversely affect the bees nutritional status, indirectly influencing the outcome of bee virus infections.

In Serbia, the first molecular research into the presence of bee viruses was conducted on 11 apiaries [68] including 55 honey bee colonies from different regions. Real-time RT-PCR detected DWV in all apiaries and ABPV in 10 out of 11. Similar, but more extensive research was done by Cirkovic et al. [69], who investigated into the prevalence 
DWV, Chronic Bee Paralysis Virus (CBPV), ABPV and the Sacbrood Virus (SBV) in colonies of different strength located in five regions of Serbia (Figure 2). The analyses detected at least one virus in $87.33 \%$ of the colonies. Single infection was found in $28.67 \%$ colonies $(21.33 \%, 4.00 \%, 2.67 \%$ and $0.67 \%$ in cases of DWV, ABPV, SBV and CBPV, respectively). In the majority of them (58.66\%) more than one virus was found. The most prevalent was DWV (74\%), followed by ABPV, SBV and CBPV (in $49.30 \%, 24.00 \%$ and $6.70 \%$ colonies, respectively). Phylogenetic studies revealed that the honey bee viruses detected in Serbia were 93-99\% identical with those deposited in GenBank.

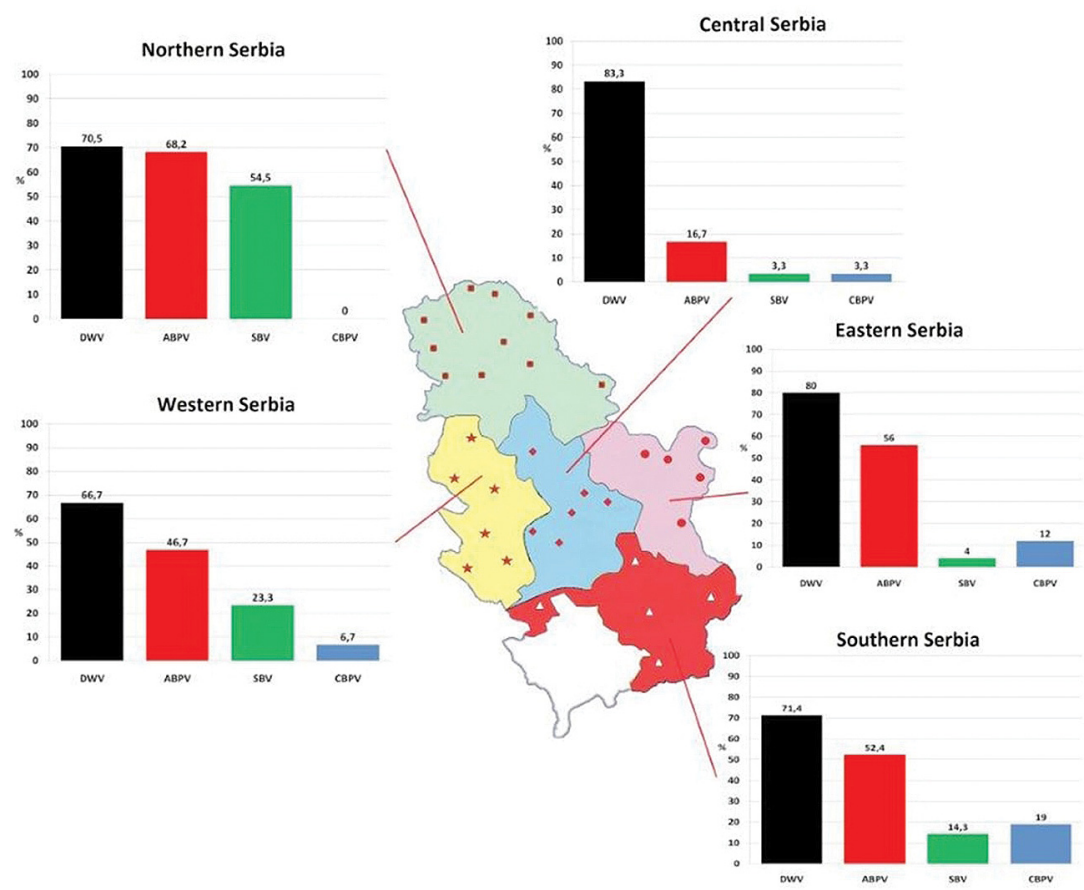

Figure 2. Prevalence patterns of investigated viruses in honey bee colonies in five regions of Serbia [69]

Considerable numbers of beekeepers in Serbia refer to the Laboratory for genetics of domestic animals, wildlife and bees (Department of Biology, Faculty of Veterinary Medicine) each year, requesting analyses of samples taken from diseased or dead colonies. In these bees, the prevalence of viruses in the five-year period (2014-2018) was: DWV 73.12-87.16\%, ABPV 61.54-81.45 and CBPV 58.82-64.22\% (Figure 3). The history of diseases, based on the beekeepers' claims, most frequently pointed to: (1) inadequate anti-varroa treatment, or its absence; (2) depriving bees of large quantities of honey and feeding them on sugar, and (3) wintering bees on sunflower honey (which is often last produced in the season and contaminated with agropesticides). 


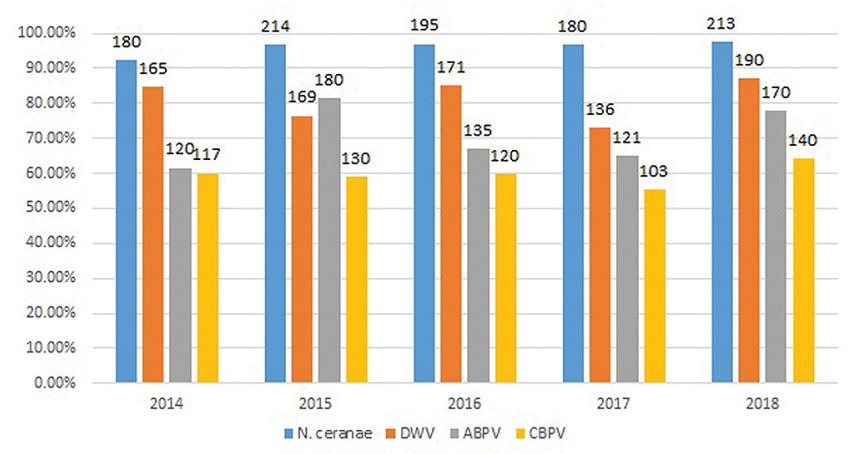

Figure 3. Presence of N. ceranae, DWV, ABPV and CBPV in bees analyzed at the Laboratory for Genetics of Domestic Animals, Wildlife and Bees, Department of Biology, Faculty of Veterinary Medicine (2014-2018)

It should be emphasized that the presence of virus infections of the brood and adult bees is influenced by apiculture technology (conventional vs. traditional). There are certain regions where bees are still kept in a traditional way, in primitive hives made of wicker - so-called trmka hives. Research conducted on the Pester Plateau, Serbia, showed that such beehives provide significantly better conditions for maintenance of bee health and their resistance to pathogens [70]. Seemingly healthy colonies kept for commercial purposes and those in primitive hives were screened for bee brood virus (SBV) and adult bee viruses (Figure 4). In traditional hives, SBV was detected in 33.33\% samples and in $96.67 \%$ in commercial colonies. Furthermore, occurrence of viruses in adult bees was significantly higher in commercial colonies (Table 1). Obviously, in the brood and adult bees reared in a traditional way, in primitive hives, the prevalence of all the viruses monitored was up to $33.33 \%$, without clinical symptoms, which is within the limits of normal distribution of viruses in bee colonies in natural conditions.

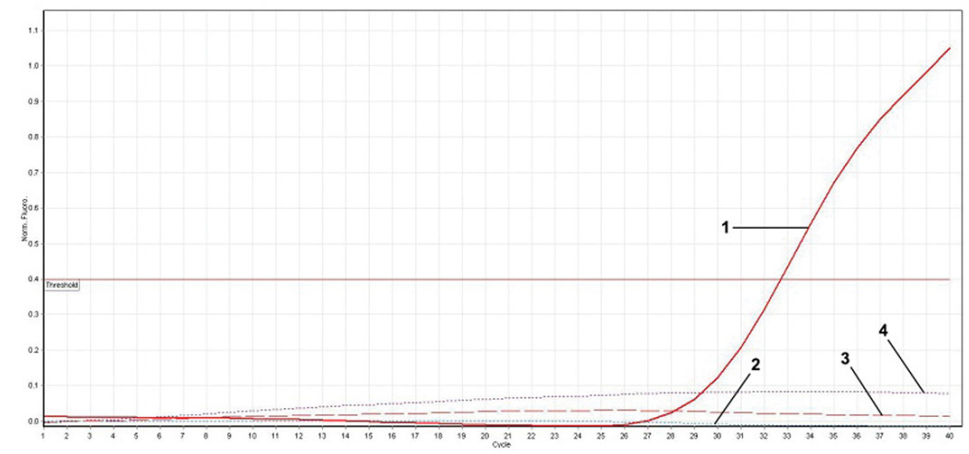

Figure 4. Amplification plots following real-time PCR demonstrating the detection of viruses in adult bees. Lines 1-4 - positive controls: 1) Blue line - for ABPV; 2) Red line - for CBPV; 3) Orange line -for DWV; 4) Green line - for SBV; Dashed lines (5-8) - samples, correspondingly. Dotted lines (9-12) - negative controls, respectively. Single replicates are shown for clarity [70]. 
Table 1. The prevalence of causative agents of bee diseases in commercial and traditionally reared bee colonies (based on the detection of their nucleic acids): 1. P. larvae, 2. M. plutonius, 3. A. apis, 4. Sacbrood virus, 5. Acute bee paralysis virus, 6. Chronic bee paralysis virus, 7. Deformed-wing virus; 8. $\sum \mathrm{N}=120$; 9. $\sum \mathrm{N}=24$ [70].

\begin{tabular}{llccc}
\hline \multirow{2}{*}{ Bee pathogens } & & \multicolumn{2}{c}{ Hives } & \multirow{2}{*}{$\boldsymbol{P}$} \\
\cline { 3 - 4 } & & Commercial $^{\mathbf{8}} \mathbf{( \% )}$ & Traditional-trmka $^{\mathbf{9}}$ (\%) & \\
\hline \multirow{4}{*}{ Brood pathogens } & $\mathrm{AFB}^{1}$ & 16.67 & 0.00 & $<0.05$ \\
& $\mathrm{EFB}^{2}$ & 0.00 & 0.00 & $>0.05$ \\
& $\mathrm{CB}^{3}$ & 15.83 & 0.00 & $<0.05$ \\
& $\mathrm{SBV}^{4}$ & 96.67 & 33.33 & $<0.01$ \\
& $\mathrm{ABPV}^{5}$ & 83.33 & 33.33 & $<0.01$ \\
Adult bee pathogens & $\mathrm{CBPV}^{6}$ & 100.00 & 33.33 & $<0.01$ \\
& $\mathrm{DWV}^{7}$ & 100.00 & 33.33 & $<0.01$ \\
\hline
\end{tabular}

Legend: 1. P. larvae, 2. M. plutonius, 3. A. apis, 4. Sacbrood virus, 5. Acute bee paralysis virus, 6. Chronic bee paralysis virus, 7. Deformed-wing virus; $8 . \sum \mathrm{N}=120 ; 9 . \sum \mathrm{N}=24$ [70]

In order to prevent huge colony losses due to mixed infections with Varroa and viruses, it is necessary to regularly control the mite, the vector of various pathogens $[55,56$, $61,62,64,69,71,72]$

There are various means of $V$. destructor control, which are successful to a varying extent. These methods are divided into biotechnical, chemical - use of synthetic 'hard' acaricides and ecological - use of 'soft' acaricides [49, 73], but may also be used in combination [74]. Long-lasting work of Stanimirović et al. [75] resulted in the development of Varroa-control strategy applicable in the Balkans (Figure 5). Biotechnical methods are time-consuming and insufficiently efficacious [74-77]. The use of 'hard' acaricides are followed by the following issues: (1) emergence of resistant mites, mainly to pyrethroids - fluvalinate and flumethrin [78-80], and (2) residues in all hive products: highest concentrations were proven in wax and propolis, lower in pollen and bee bread, and lowest in honey [49, 79, 81-84]. The most often detected varroacides in beeswax, pollen and bee bread are fluvalinate, coumaphos, amitraz and bromopropylate [84-89] and chlorfenvinphos in wax and bee bread samples from Spain [90]. Given that wax is a hive constituent which takes longest to be renewed, pesticides which remain in the hive may lead to the so-called 'toxic home syndrome'. This problem cannot be solved by wax replacement because residues of lipophilic acaricides remain in beeswax even after recycling [89]. Finally, synthetic acaricides may be harmful to bees and affect their reproductive traits and behavior, if not used correctly [43, 46, 48, 91, 92].

As a consequence of all the diagnosed problems arising from the use of synthetic acaricides, those which are natural-product-based, for example, organic acids and plant extracts, have come into widespread use [49, 73, 93]. Their efficacy has been tested for more than two decades [73, 93-96]. Formic, oxalic and lactic acids are organic 
acids (OA) in use for the control of Varroa mites. Among plant extracts, essential oils (EO) and their components are by far the most studied for varroacide activity $[75,84]$. General advantages of natural compounds, both OA and EO, are a low risk of residues and accumulation in bee products, and the low probability of eliciting resistance after repeated treatments [49]. If used properly, their residues are low and the image of honey and other bee products as natural, healthy and clean remain untarnished. However, OA and EO have significant disadvantages: their efficacy is insufficient and depends on climatic and in-hive conditions, and means of application $[49,75,93]$. Some natural preparations exert side effects on bees and/or their brood [95, 97]. Luckily, some plant-derived formulations, rather effective, but without unwanted effects on colony development and productivity have been used recently $[73,96]$. To sum up, neither of the methods of mite control, which has been used and investigated until now, can meet all these criteria: be safe for bees, highly efficacious against Varroa mites and easy to use. However, successful Varroa control is achievable if done in compliance with regulations concerning regular spring and autumn bee health monitoring by licensed veterinarians, who can propose adequate treatments.

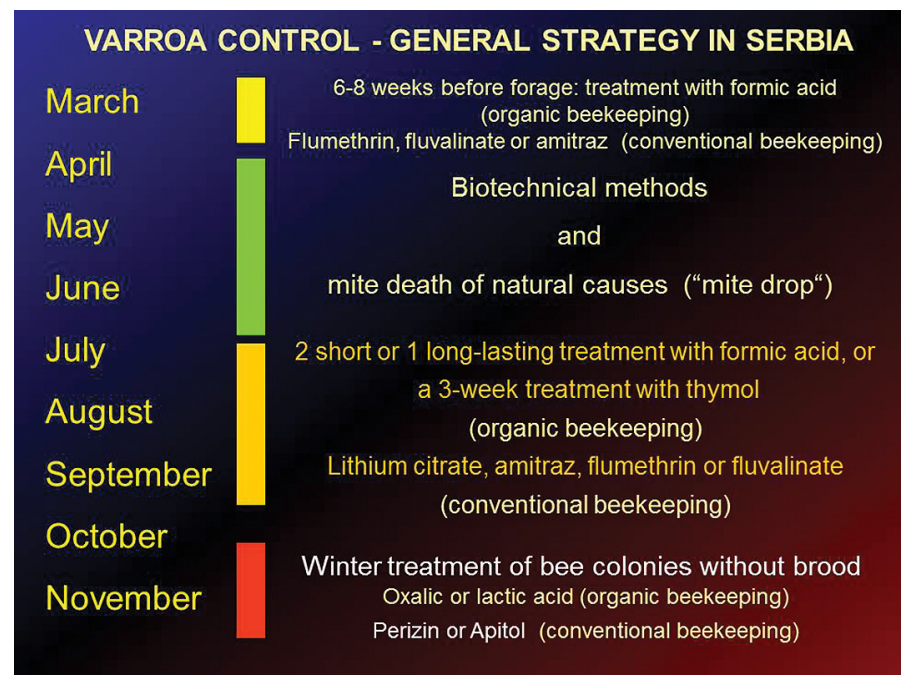

Figure 5. Varroa control - general strategy in Serbia

Recently, in scientific circles, an idea was pushed forward that various lithium compounds may be used in Varroa control. Research carried out by Ziegelmann et al. [98] suggests that lithium salts may produce a marked acaricide effect. Our recent research proved the efficacy of lithium-salt-based supplements (Figure 6A), especially those containing lithium citrate in various concentrations. Results showed that concentrations of 5 and $7.5 \mathrm{mM}$ exerted a powerful acaricide effect, not affecting bee mortality (Figure 6A). In field experiments, the tested concentration $(7.5 \mathrm{mM})$ had a satisfactory acaricide effectiveness (Figures 6B and 6C). 


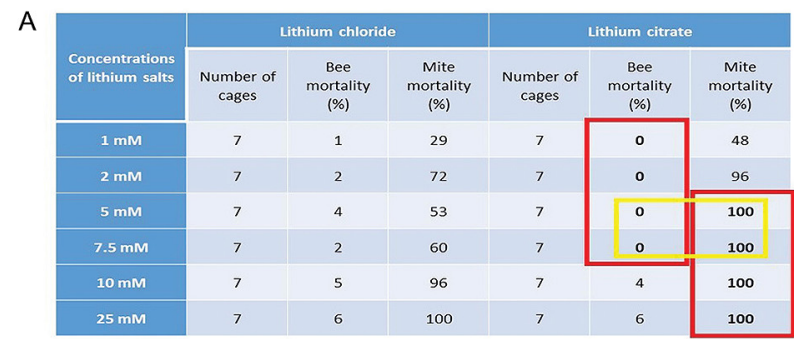

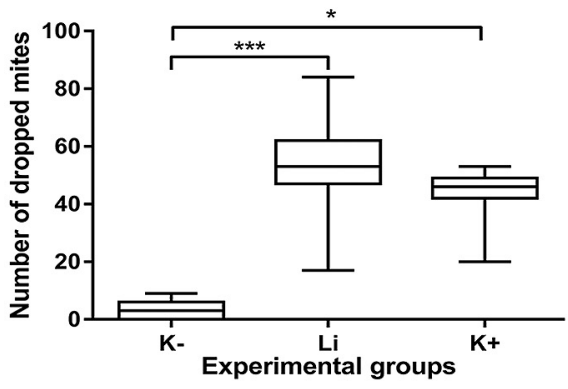

$\mathrm{C}$

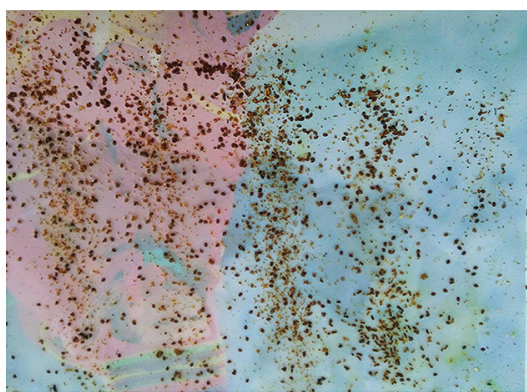

Figure 6. A) Anti-varroa effect of different lithium chloride and lithium citrate concentrations in a seven-day cage experiment; B) Anti-varroa effects of $7.5 \mathrm{mM}$ lithium citrate. K- Negative control group (non-treated); Li - Group treated with lithium citrate; $\mathrm{K}+$ Positive control (amitraz treated); C) Mites fallen following lithium citrate treatment.

\section{Bacterial infections (American and European foulbrood) and fungal diseases (ascosphaerosis and nosemosis)}

Bacterial diseases of special interest for the honey bee brood are American and European foulbrood [99]. Besides these bacterial diseases, an invasive and destructive mycosis caused by Ascosphaera apis should be considered as a contributor to honey bee health weakness [100]. Aspergillus spp., a cosmopolitan fungus, deserves greater attention because of its high virulence towards honey bee larvae and the ubiquity of its spores [101].

American foulbrood (AFB) is considered to be a fatal bee brood disease [50]. In some countries it is frequent (e.g. $5-10 \%$ bee colonies in Germany were found to be infected without symptoms) and causes considerable economic losses to the beekeeping industry. Clinical signs and the course of AFB disease vary, depending on the Paenibacillus larvae genotype, and the strength and behavioral defense mechanisms of bee colonies. The identification of $P$. larvae genotypes (made with rep-PCR) is important because of the differences in virulence and prognosis: genotypes ERIC I and II do not kill larvae in the early stage, but only after the comb cells are sealed, which is why hygienic bees cannot clean the diseased brood effectively and the disease outbreaks, i.e. clinical symptoms become visible [102]; genotypes ERIC III and IV are highly virulent towards larvae, which is why the majority of them die before the cells are sealed, and hygienic bees clean the detritus and the classical disease symptoms are most often missing. These $P$. larvae genotypes differ in germination ability, resistance 
to different temperature treatment and storage, which is why their genotyping should be checked, as part of standard laboratory protocols [103].

Generally, European foulbrood (EFB) is spread in honey bees worldwide, that causes serious losses of brood and colony collapse [104]. For example, in Switzerland and Great Britain, EFB has posed great problems [105, 106] due to the failure of the sanitary measures applied, which led to the necessity of solving the problem of the spreading of $M$. plutonius [50]. Apart from classical microbiological methods of detection, certain molecular analyses for the conformation of $M$. plutonius have been developed based on PCR techniques [70, 106, 107].

Chalkbrood disease is often neglected when looking for the causes of colony losses, owing to the fact that the presence of $A$. apis is easily recognized and the infection diagnosed [108]. A. apis causes high brood mortality and significant decline in bee population in the hive. Strong colonies solve the problem by recruiting high numbers of hygienic worker bees, which easily recognize and get rid of "calcified" larvae, so the majority of these colonies heal in a short period of time [109]. However, chalkbrood disease may contribute to colony losses, especially those compromised by various etiological agents. The emergence of these diseases depends also on beekeeping techniques $[12,70]$.

Research was conducted on the Pester Plateau, Serbia [70] on seemingly healthy colonies kept in a traditional way, in primitive hives, and those in commercial hives. The colonies were screened for P. larvae, M. plutonius and A. apis (Figure 7). Traditional

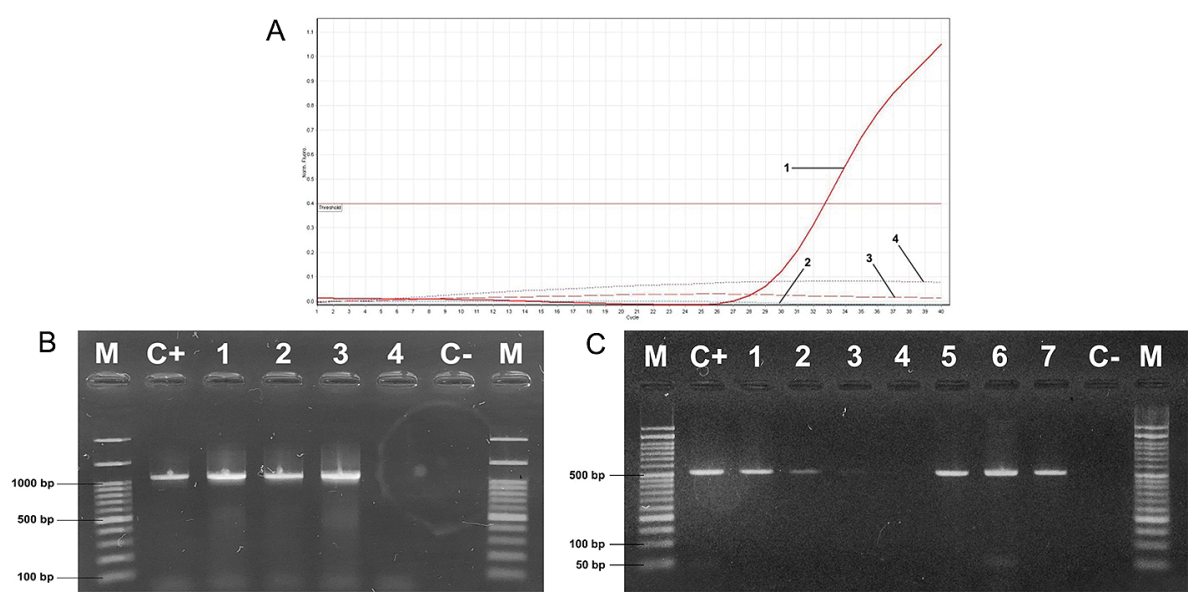

Figure 7. A) Amplification plots following real-time PCR demonstrating the detection of M. plutonius in brood samples. Continuous line (1) - positive control for M. plutonius; Dotted lines, blue and purple (2 and 4) - samples; Dashed line (3) - negative control [70]; B) Visualization of the PCR amplification products of P. larvae isolates. M - 100 bp ladder DNA marker; C+ positive control; 1-4 - samples; C- negative control. The sizes of the positive bands are indicated on the left [70]; C) Gel electrophoresis of DNA amplification products from the fungal isolates A. apis. M, 50 bp ladder DNA marker; $\mathrm{C}+$, positive control; C- negative control; 1-2) samples. The sizes of the positive bands are indicated on the right [70]. 
beehives provided significantly better conditions for maintenance of bee health and their resistance to pathogens: they were free from bacterial or fungal brood pathogens. By contrast, in commercial colonies P. larvae (16.67\%), A. apis (15.83\%) were detected, but $M$. plutonius was not found. Two thirds of traditionally kept colonies were without any of the bee pathogens checked, but not any of those kept for commercial purposes was free from all pathogens (Table 1).

Nosemosis. Microsporidians and trypanosomatids and are the most abundant eukaryotic gut parasites of honey bees [110-114] and have been correlated with increased colony losses, although their role is still controversial [115-118]. There are three microsporidian species which may infect $A$. mellifera: Nosema ceranae, most prevalent and globally distributed [116, 119], N. apis, which prevails over $N$. ceranae only in cold climates [120-122], and N. neumanni, a recently described species, endemic in Uganda, causing low-level infection [123].

$N$. ceranae is thought to be a serious threat to the beekeeping industry, but dramatic colony losses were clearly attributed exclusively to $N$. ceranae infections in some regions only [124-126]. N. ceranae as a sole stressor showed suppressive effects on immunerelated genes (Figure 8) in laboratory experiments [127-129]. However, in all pieces of research there was a time-dependent inconsistence in gene expression.

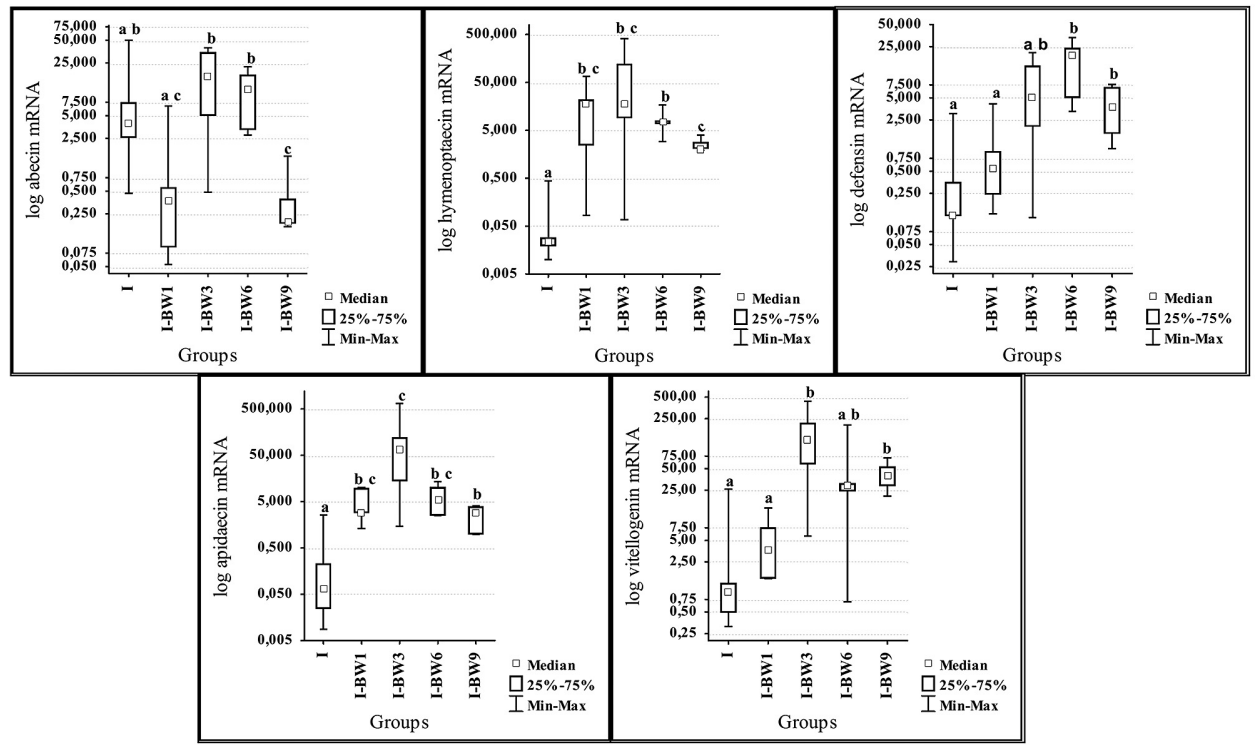

Figure 8. Expression levels of genes for abaecin, hymenoptaecin, defensin, apidaecin and vitellogenin on day 12 after the infection with $\mathrm{N}$. ceranae in groups treated with "BEEWELL AminoPlus". Groups were infected with N. ceranae spores on 3rd day after emerging and treated with "BEEWELL AminoPlus" from 1st (I-BW1), 3rd (I-BW3), 6th (I-BW6) and 9th (I-BW9) day, while the control group (I) was infected with N. ceranae but not treated. Different letters denote significant differences between groups [129]. 
It has been proven by molecular diagnostics that N. ceranae is a dominant microsporidian pathogen of honey bees in Serbia [110,111]. Among all bee samples collected from 2000 onwards, only one (originating from 2008) was proven to be infected with $N$. apis, whilst all other positive bees were infected with $N$. ceranae $[110,111]$. Thus, it became clear that $N$. ceranae has been present in Serbia since at least 2000, and could not be regarded as an emergent pathogen in this region. Due to the absence of any molecular evidence that $N$. apis has ever been prevalent in Serbia, there is no ground for discussion about the replacement of $N$. apis with $N$. ceranae.

As regards the prevalence of $N$. ceranae in Serbian honey bee colonies, it was continually high, ranging from 73 to $98 \%$ (2008-2012). The highest was always recorded in March and ranged from 94 (2008) to 98\% (2010). Lower, but still considerable proportions of infected colonies were detected in October (76-87\%) and June (73-91\%), according to Stevanovic et al. [111]. Nevertheless, the features of nosemosis type $\mathrm{C}$ caused by N. ceranae [130] in Spain (lack of seasonality, the absence of any clear symptoms and the inevitable collapse of infected colonies if not treated), have never been recorded in N. ceranae-infected bees in Serbia [111]. In fact (1) a seasonal pattern was affirmed in N. ceranae incidence in period 2008-2011; (2) the symptoms traditionally attributed to $N$. apis infection (faecal marks, dead and sick crawling bees) were observed in the majority of $N$. ceranae-infected colonies; (3) no clear association between $N$. ceranae infection and colony losses was confirmed neither during the winter nor during the summer season [111]. As the symptoms of nosemosis were found in both surviving and dead colonies, being even more frequent among the former, these could not be indicative of colony losses. The same counts for some additional observations recorded in $N$. ceranae-infected colonies in winter: loose cluster in cold winter days (temperatures below $-5^{\circ} \mathrm{C}$ ) opposite to compact ones in non-infected colonies, and increased anxiety in bees at mild winter temperatures $\left(0^{\circ} \mathrm{C}\right.$ or slightly higher $)$ manifested through an unusually high number of bees on the hive entrance after sound disturbing [111]. In compliance with all these is the finding that in adult bees collected due to visible symptoms of diseases and delivered to our laboratory the prevalence of $N$. ceranae in a five-year period (2014-2018) was $92.31-97.71 \%$ (Figure 3). To conclude, $N$. ceranae infection in Serbian bees, in the absence of other stressors, does not resemble nosemosis type $\mathrm{C}$ and exerts no marker indicative of colony losses.

$N$. ceranae may be blamed for the decrease in the bees' reproductive capacities and honey production [131]. Its impact was investigated in equalized colonies headed by queens of different age (one-, two- and three-year old) having in mind that in the queen exhausted by N. ceranae infection the renewal of the worker population might be compromised. Besides reproduction and productivity, in the three-year period (20092012), N. ceranae was monitored and quantified (spore load per colony). Significantly higher reproductive and productive values were recorded in colonies headed by younger queens (Table 2). This may be explained with their higher capacity to compensate the effects of $N$. ceranae infection, which gradually declines as they are getting older [131]. 
Table 2. The influence of $N$. ceranae spore loads on parameters of reproduction and productivity in colonies with queens of different age [131]

\begin{tabular}{lccccc}
\hline & \multicolumn{2}{c}{ ANOVA } & \multicolumn{3}{c}{ Bonferroni test } \\
\cline { 2 - 6 } Parameter & Age of the queen & $\begin{array}{c}\text { One-year } \\
\text { old queens/ } \\
\text { Two-year } \\
\text { old queens }\end{array}$ & $\begin{array}{c}\text { One-year } \\
\text { old queens/ } \\
\text { Three-year } \\
\text { old queens }\end{array}$ & $\begin{array}{c}\text { Two-year } \\
\text { old queens/ } \\
\text { Three-year } \\
\text { old queens }\end{array}$ \\
\cline { 2 - 6 } & $\mathbf{F}$ & $\mathbf{P}$ & $\mathbf{p}$ & $\mathbf{p}$ & $\mathbf{p}$ \\
\hline Brood size/ N. ceranae & 159.67 & $<0.001$ & $<0.001$ & $<0.001$ & 0.404 \\
Queen egg-laying rate / N. ceranae & 106.42 & $<0.001$ & $<0.001$ & $<0.001$ & 0.181 \\
Total extracted honey / N. ceranae & 201.90 & $<0.001$ & $<0.001$ & $<0.001$ & 0.007 \\
Winter honey stores / N. ceranae & 142.69 & $<0.001$ & $<0.001$ & $<0.001$ & 0.266 \\
\hline
\end{tabular}

Far more frequently it was detected that $N$. ceranae and synergistic factors have deleterious effects on bees. For example, concurrent presence of N. ceranae and viruses have been confirmed to be capable of producing severe losses of honeybee colonies [132-134], while combinations of N. ceranae and pesticides were proved to increase the mortality of bees and alter the expression of immunity-related genes [135-138]. However, in the case of $N$. ceranae and thiacloprid combination, only the higher pesticide dose elicited significant mortality in bees, since thiacloprid showed a negative impact on N. ceranae reproduction [139].

Neonicotinoids were most frequently investigated for their influence on honey bee survival, health, behavior, immunity and reproductive and productive performances. Although numerous studies failed to provide a consistent conclusion, mostly due to the discrepancy between laboratory and field tests [140,141], recent investigations provided the evidence that neonicotinoids exert significant negative effects on the health and survival of honey bees [142], their behavior [143], the reproductive capacity of drones [144], and that at field concentrations they may impair the immune defense $[145,146]$. Comprehensive assessments of risks for bees by exposure to pesticide residues indicated the highest risk of contact exposure to pyrethroid and neonicotinoid residues via contaminated pollen. Moreover, neonicotinoids pose much higher risks in combination with ergosterol biosynthesis-inhibiting (EBI) fungicides because of their synergistic interactions [5, 147, 148], or in-hive miticides - tau-fluvalinate, coumaphos and fenpyroximate [149]. One of EBI fungicides is prochloraz, widely used in horticulture and agriculture, which has been detected in honey and pollen stored in hives [150]. It was previously found to increase almost 1,000-fold the toxicity of tau-fluvalinate, and more than 20-fold that of coumaphos and fenpyroximate [149]. Moreover, prochloraz altered the immune-gene expression in honey bees used alone and in combination with coumaphos [63,151]. Recently, Glavinic et al. [138] monitored the expression of 15 immune-related genes in adult honey bees, and found that it may be affected when food contaminated with prochloraz was consumed by bee larvae 
(Figure 9). The results were obtained using a combination of a field and laboratory experiment which simulated the conditions where N. ceranae-infected and uninfected bee colonies are close enough to crop fields treated with prochloraz. Therefore, a great probability of crop contamination and, consequently, of the brood intended to produce the population of winter bees is likely. This new experimental approach introduced by Glavinic et al. [138] enables the insight into the realistic situation when beekeepers move their hives to sunflower forage, which is frequently the last one, so the bees are wintered on sunflower-derived food. In the control of Nosema infection the introduction of good apitechnical practice is proposed, which includes: replacement of the queen with a new, young, promiscuous and healthy one [152], feeding colonies with high-quality food (honey and bee bread), additional feeding with sugar syrup enriched with pollen and/or supplements, disinfection of hives and other equipment, sterilization of combs and removal of excess humidity from the hives. In addition, healthy and diseased hives should never be joined. In some countries, the antibiotic fumagillin is still used for Nosema control. The effectiveness of fumagillin was recently re-evaluated and proven in both laboratory and field conditions [153, 154], but may depend on storage, treatment preparation and the quantity consumed by bees etc. [153]. In Serbia, like in the majority of the world, the use of fumagillin is not recommended due to its adverse effects on bees [154,155], the quality of bee products and consumer health, which result from its inadequate use [44, 45, 47, 156, 157].

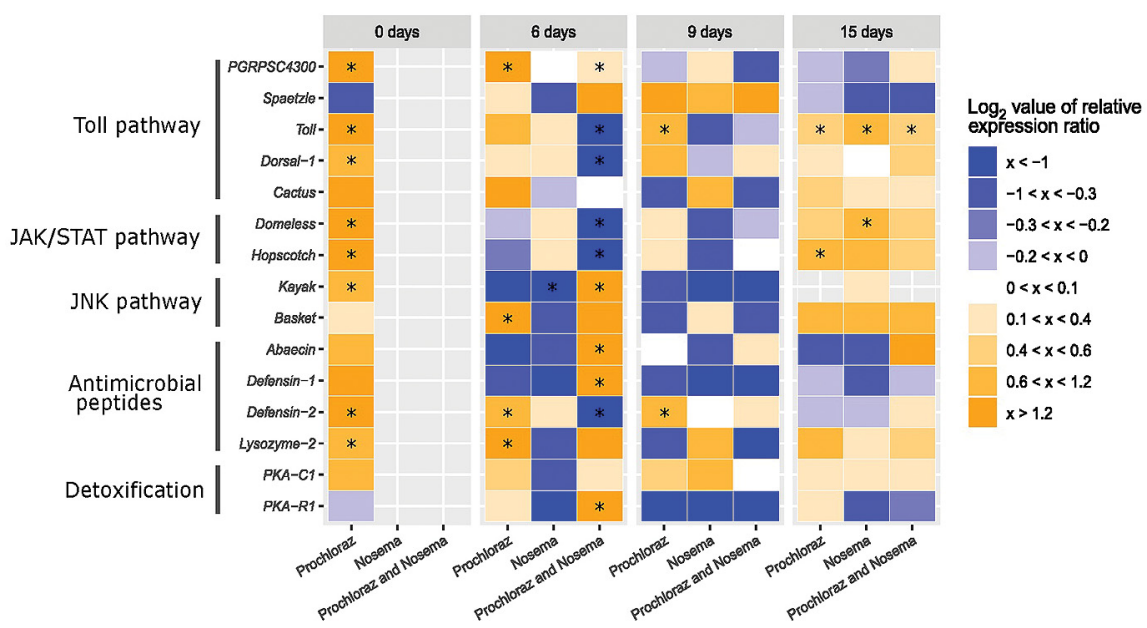

Figure 9. Heatmap immune-related genes in adult honey bee at different ages (0-, 6-, 9- and 15-days after honey bee emergence). The colors indicate the average mRNA levels compared to average levels of mRNA in control groups: blue indicates lower and yellow higher levels. Range $\log 2$ value of relative expression ratio is indicated in the legend on the right. Each row corresponds to one gene transcript and each column, to the expression profile of treatment. The gene names and the corresponding pathway are indicated on left side. Treatments are indicated in the scale at the bottom of the graph (Nosema-infected, CN; Prochloraz-treated, P; Prochloraz treated and Nosema-infected, PN). Control group (C) was used for normalization. Boxes marked with an asterisk show statistically significant effects of the treatment on gene expression, when p-value was equal or less than 0.05 [138]. 
Trypanosomal infections. Of the two trypanosomatid parasites of A. mellifera, Crithidia mellificae has been known for approximately 50 years and was considered widespread until recently, when Lotmaria passim was first described. The latter turned out to be predominant when detailed genetic analyses were performed [113]. Some investigators [158-162] suggested the possible involvement of trypanosomatids in honey bee health, their immune response and in winter colony losses. Investigations into the pathological effects of $C$. mellificae and $L$. passim on honey bees require primarily molecular tools for identification of these trypanosomatids, so Stevanovic et al. [112] designed and validated primers capable of distinguishing between C. mellificae and L. passim in conventional PCR, which enables routine research on their prevalence and epizootiology [163]. Moreover, primers for a real-time PCR were designed and the method optimized, which allows the simultaneous detection and quantification of $L$. passim and its in-depth field monitoring [114].

In the first long-lasting investigation into the presence of the two Trypanosoma species in the world, archived bee samples taken in Serbia (2007-2015) were analyzed, but only one species was detected, L. passim, with an annual prevalence of 38.9-83.3\%, and $62.3 \%$ on average in the nine-year period. The same samples were also checked for $N$. ceranae, which was found in most samples with an overall frequency of $95.7 \%$, ranging annually from $83.3 \%$ to $100 \%$. Only $1.9 \%$ was infected with $L$. passim alone, while L. passim and N. ceranae simultaneously parasitized the same host at a fairly high rate: $60.5 \%$, (Table 3). What is more, the detection of $L$. passim in bees sampled in 2007 in Serbia is its oldest genetically proven conformation globally and the first one in Serbia [112].

Table 3. Summarized annual honey bee colony sampling in Serbia and infection status with Lotmaria passim and/or Nosema ceranae from 2007 to 2015 [112].

\begin{tabular}{lcccc}
\hline Year $^{2}$ & $\begin{array}{c}\text { L. passim } \\
\text { infection } \\
\text { only }\end{array}$ & $\begin{array}{c}\text { N. ceranae } \\
\text { infection } \\
\text { only }\end{array}$ & Co-infection & Uninfected \\
\hline 2007 & 0 & 5 & 13 & 0 \\
\hline 2008 & 0 & 11 & 7 & 0 \\
\hline 2009 & 0 & 5 & 13 & 0 \\
\hline 2010 & 1 & 4 & 10 & 3 \\
2011 & 0 & 3 & 15 & 0 \\
\hline 2012 & 2 & 2 & 13 & 1 \\
2013 & 0 & 11 & 7 & 0 \\
\hline 2014 & 0 & 6 & 12 & 0 \\
2015 & 0 & 10 & 8 & 0 \\
\hline Total: & $3(1.9 \%)$ & $57(35.2 \%)$ & $98(60.5 \%)$ & $4(2.5 \%)$ \\
\hline
\end{tabular}

${ }^{1}$ All samples tested negative for $N$. apis and C. mellificae.

${ }^{2} 18$ colonies were sampled each year using 60 adult bees per colony. 
A high positive correlation $(\mathrm{p}<0.0001)$ between $L$. passim and $N$. ceranae infection levels pointed to their similar annual dynamics. Significant differences $(p<0.05)$ in infection levels with both species between months implies the seasonal character of their prevalence. Highest parasite burdens with N. ceranae and L. passim were detected in forager bees sampled in winter and lowest in those taken in mid-summer [114].

Lower activity of superoxide dismutase (SOD), increased activities of catalase (CAT) and glutathione S-transferase (GST) and higher concentrations of malondialdehyde (MDA) in the season, imply that L. passim infection induces oxidative stress, which may negatively influence the condition and productivity of bees, and, consequently, render beekeeping less economical [164].

\section{General management in the apiary}

Apitechnical practice today relies on depriving bees of excessive amounts of honey. The basic principles of this idea date from the 1960s, in absolutely different conditions regarding climate, floristic diversity and agrotechnique. The climate has changed globally: there is less capillary humidity in the soil due to long-lasting periods of draught and recession of ground waters, which resulted in the decline in the diversity of melliferous plants. Moreover, global agricultural chemisation as well as chemical apitechnical measures aimed at the control of bee pathogens in the colony, result in contamination of in-hive products $[84,165,166]$. Care should be taken to place the apiaries in the areas with ample forage and clean water. The vicinity of the forage and the numbers of bee colonies in the area per square kilometer hugely influence bee health and the production and reproductive capacities of bee colonies [23]. The distance between apiaries should be at least $1.5 \mathrm{~km}$, to avoid competition for food collection, regardless of the quality of the forage, which means that the overpopulation of melliferous areas with hives should be avoided [167].

Technical revolution and the development of electric and communication systems strongly influence the orientation of bees when searching forage and returning to hives, the development of brood and the colony as a whole. Thus, care must be taken when deciding where to place apiaries: they should be far from overhead power lines and base radio stations [168-170].

Inadequate bee feeding with sugar syrup in order to make up for insufficient food reserves in years of famine, may also result in compromised condition and health of bee colonies and, finally, to colony losses. This is why beekeepers should know how to prepare bee food and when to provide bees with it. Sole sugar is a "necessary evil", and literature data suggest that it is much better to prepare and apply sugar-honey syrup (e.g. 7:3 sugar-honey ratio). The presence of honey, which contains a variety of active components, helps summer bees to transform it into the form nutritionally most useful to the bees. Beekeepers should know that bee feeding is sensible at the end of summer (e.g. in Serbia 1 August - 15 September), when there are enough summer bees, which are the only ones capable of transforming syrup into a satisfactory form 
for bee feeding. The use of supplements with sugar syrup should not be avoided, since they provide sufficient amino acids, peptides, micro- and macroelements which are absent from pure sugar syrup [18]. The use of supplements may prevent energetic, immune and oxidative stress in bees, and thus prevent losses in apiaries [129, 171-174]. The presence of a young, healthy bee queen in the hive guarantees the development of healthy bee colonies and successful beekeeping [131, 175]. Suitable pathogen control in hives, primarily of the bee mite $V$. destructor, with effective, registered varroacides is also a prerequisite for maintaining bee colonies in a good health condition. In addition, a strong link was detected between colony losses and beekeepers' education and training: professionals were capable of keeping colonies free from diseases, unlike hobbyists $[12,70]$. Professionals promptly detected symptoms, especially those of American foul brood or Varroa infestation, and timely applied control measures, contributing to the survival of their colonies. This was the first time that scientists focused attention on the impact of apiculturists and beekeeping practices on colony losses. The same authors commented that the introduction of a bee killer, Varroa mite, to Europe at the beginning of 1980s, did not result in increased colony losses. This was explained by the fact that beekeepers efficiently adopted measures to combat against the mite [12].

\section{CONCLUSIONS}

Scientific consensus has been reached that colony losses (CCD) are a multifactorial issue $[3,4,6]$, which follows various conditions, but, according to our observations, it develops through a sequence of steps. Firstly, various non-specific factors (e.g. climate changes, agrochemisation and inadequate food) decrease the strength of the colonies; apitechnical faults (depriving bees of too much honey and a consecutive addition of large quantities of sugary food, inadequate treatments of colonies mainly against $V$. destructor, high stress and exhausting of bees, wintering colonies on honey contaminated with pesticides - sunflower honey, bad timing for wintering the colonies etc.). Such colonies easily become eligible for bacterial, microsporidial and trypanosomal infections. Manifested nosemosis combined with Lotmaria infection and latent American foulbrood infection, additionally exhaust bee colonies and impair the immune system of the bee [176-179]. Finally, inadequate anti-varroa strategies lead to significant health problems in bees and the spread of viruses for which Varroa is a vector, and/or activator. The whole process is a path prepared for the manifestation of virus infections. This has been supported by the results of our Laboratory, which confirmed high level of viruses in samples of diseased colonies accompanied by heavy loads of $N$. ceranae spores. The fact that in colonies with disease symptoms more spores were detected than in dead colonies, supports our hypothesis that after the Nosema-infection peak (when the immunity is lowest) bee viruses are activated and gradual decrease in Nosema load occurs. Viruses, already present in hives in Serbia [68, 69], are "waiting for the time of decreased immunity", become the ultimate executors of bee colonies, often leading to colony losses. 
Given that this is a multifactorial issue, recommended solutions to the problem consist of a sequence of activities aimed at as many as possible individual factors:

- Compliance with good beekeeping practices and hygienic measures, both in the apiary and the hives, as well as in the facilities where beekeeping material, equipment and bee products are stored

- Positioning the apiary to places with ample melliferous plants and clean water

- Avoiding areas where pesticides are used intensively, which may, if present in nectar and pollen, enter the hive and harm bees' health and leave residues in the bee products

- Breeding healthy autochthonous bee colonies with young and healthy bee queens and compliance with bee selection programmes

- Providing enough quantities of honey, pollen and bee bread for colonies during winter

- The remaining honey, pollen, bee bread from hives which suffered from colony loss is not to be used for feeding healthy colonies. If the bees do not provide enough food, the shortage should be compensated with honey-sugar syrup or sugar syrup with the addition of supplements

- Beekeeping today is impossible without acaricides to get rid of Varroa mites. Anti-varroa treatments should be done with registered preparations, applied in the adequate period of the year. Combinations of preparations may be used to increase the efficacy, taking into consideration the interactions between them.

\section{Acknowledgements}

This study was supported by the Ministry of Education, Science and Technological Development of the Republic of Serbia, by awarding a grant for Research Project No. III46002, led by Professor Zoran Stanimirovic.

\section{Authors' contributions}

All authors (SZ, GU, RM, AN, JN, VB and SJ) contributed in manuscript design, performed literature searches, wrote and revised the article and approved the final manuscript.

\section{Declaration of conflicting interests:}

The author(s) declared no potential conflicts of interest with respect to the research, authorship, and/or publication of this article. 


\section{REFERENCES}

1. Gallai N, Salles JM, Settele J, Vaissière BE: Economic valuation of the vulnerability of world agriculture confronted with pollinator decline. Ecol Econ 2009, 68:810-821.

2. Moritz RFA, de Miranda J, Fries I, Le Conte Y, Neumann P, Paxton R: Research strategies to improve honeybee health in Europe. Apidologie 2010, 41:227-242.

3. vanEngelsdorp D, Meixner MD: A historyical review of managed honey bee populations in Europe and the United States and the factors that may affect them. J Invertebr Pathol 2010, 103:S80-S95.

4. Neumann P, Carreck NL: Honey bee colony losses. J Apicult Res 2010, 49:1-6.

5. Sanchez-Bayo F, Goka K: Pesticide residues and bees - a risk assessment. PLoS ONE 2014, 9:e94482.

6. Goulson D, Nicholls E, Botías C, Rotheray EL: Bee declines driven by combined stress from parasites, pesticides, and lack of flowers. Science 2015, 347:1255957.

7. McMenamin AJ, Genersch E: Honey bee colony losses and associated viruses. Curr Opin Insect Sci, 2015, 8:121-129.

8. Sanchez-Bayo F, Goulson D, Pennacchio F, Nazzi F, Goka K, Desneux N: Are bee diseases linked to pesticides? - A brief review. Environ Int 2016, 89:7-11.

9. FAO - Food and Agriculture Organization of the United Nations: Pollinators vital to our food supply under threat. 2016, http://www.fao.org/news/story/en/item/384726/icode/.

10. Kulhanek K, Steinhauer N, Rennich K, Caron DM, Sagili RR, Pettis JS, Ellis JD, Wilson ME, Wilkes JT, Tarpy DR, Rose R, Lee K, Rangel J, vanEngelsdorp D. A national survey of managed honey bee 2015-2016 annual colony losses in the USA. J Apicult Res 2017, 56:328-340.

11. Ellis JD, Evans JD, Pettis J: Colony losses, managed colony population decline, and colony collapse disorder in the United States. J Apicult Res 2010, 49:134-136.

12. Jacques A, Laurent M, EPILOBEE Consortium, Ribière-Chabert M, Saussac M, Bougeard S, Budge GE, Hendrikx P, Chauzat M: A pan-European epidemiological study reveals honey bee colony survival depends on beekeeper education and disease control. PLoS ONE 2017, 12:e0172591.

13. Brodschneider R, Gray A, Adjlane N, Ballis A, Brusbardis V, Charrière JD, Chlebo R, Coffey MF, Dahle B, de Graaf DC, Dražić MM, Evans G, Fedoriak M, Forsythe I, Gregorc A, Grzęda U, Hetzroni A, Kauko L, Kristiansen P, Martikkala M, Martín-Hernández R, Medina-Flores CA, Mutinelli F, Raudmets A, Ryzhikov VA, Simon-Delso N, Stevanovic J, Uzunov A, Vejsnæs F, Wöhl S, Zammit-Mangion M, Danihlík J: Multi-country loss rates of honey bee colonies during winter 2016/2017 from the COLOSS survey. J Apicult Res 2018, 57:452-457.

14. vanEngelsdorp D, Evans JD, Saegerman C, Mullin C, Haubruge E, Nguyen BK, Frazier M, Frazier J, Cox-Foster D, Chen Y, Underwood R, Tarpy DR, Pettis JS: Colony collapse disorder: a descriptive study. PLoS ONE 2009, 4:e6481.

15. Cox-Foster DL, Conlan S, Holmes EC, Palacios G, Evans JD, Moran NA, Quan PL, Briese T, Hornig M, Geiser DM, Martinson V, vanEngelsdorp D, Kalkstein AL, Drysdale A, Hui J, Zhai J, Cui L, Hutchison SK, Simons JF, Egholm M, Pettis JS, Lipkin WI: A metagenomic survey of microbes in honey bee colony collapse disorder. Science 2007, 318:283-287.

16. Oldroyd BP: What's killing American honey bees? PLoS Biol 2007, 5:e168. 
17. EFSA (European Food Safety Authority): Towards holistic approaches to the risk assessment of multiple stressors in bees. EFSA Scientific Colloquium Summary Report, 15-16 May 2013, Parma, Italy.

18. Lipinski Z, Honey bee nutrition and feeding, in the temperate/continental climate of the northen hemisphere, OZGraf S.A., Olsztyn - A.D., 2018, 1-430.

19. Vanbergen AJ, Insect Pollinators Initiative. Threats to an ecosystem service: pressures on pollinators. Front Ecol Environ 2013, 11:251-259.

20. Di Pasquale G, Salignon M, Le Conte Y, Belzunces LP, Decourtye A, Kretzschmar A, Suchail, S, Brunet JL, Alaux C. Influence of pollen nutrition on honey bee health: do pollen quality and diversity matter? PLoS ONE 2013, 8:e72016.

21. Asensio I, Vicente-Rubiano M, Muñoz MJ, Fernández-Carrión E, Sánchez-Vizcaíno JM, Carballo M: Importance of ecological factors and colony handling for optimizing health status of apiaries in Mediterranean ecosystems. PLoS ONE 2016, 11:e0164205.

22. Stanimirović Z, Soldatović B, Vučinić M: Honey bee - Biology of the bees [in Serbian] Beograd, Srbija: Medicinska knjiga - Medicinske komunikacije 2000, 1-375.

23. Cirkovic D, Stanimirovic Z: Beekeeping manual [in Serbian] Državni univerzitet u Novom Pazaru, Naučna KMD, Beograd, 2018, 1-241.

24. Williams GR, Tarpy DR, vanEngelsdorp D, Chauzat MP, Cox-Foster DL, Delaplane KS, Neumann P, Pettis JS, Rogers ELR, Shutler D: Colony collapse disorder in context. Bioessays 2010, 32:845-846.

25. Stanimirović Z, Ljubenković J, Stanimirović M, Stevanović J: Eneregetski stres kod medonosne pčele izazvan infekcijom Nosema ceranae. Drugi državni pčelarski sajam, 2010a. Savez Pčelarskih Organizacija Srbije, 41-48.

26. DeGrandi-Hoffman G, Yanping Chen, Huang E, Huang MH. The effect of diet on protein concentration, hypopharyngeal gland development and virus load in worker honey bees (Apis mellifera L.). J Insect Physiol 2010, 56:1184-1191.

27. Chensheng, LU, Warchol, KM, Callahan RA: Sub-lethal exposure to neonicotinoids impaired honey bees winterization before proceeding to colony collapse disorder. B Insectol 2014, 67:125-130.

28. Wheeler MM, Robinson GE: Diet-dependent gene expression in honey bees: honey vs. sucrose or high fructose corn syrup. Sci Rep 2014, 4:5726.

29. Nikolić T, Purać J, Orčić S, Kojić D, Vujanović D, Stanimirović Z, Gržetić I, Ilijević K, Šikoparija B, Blagojević D: Environmental effects on superoxide dismutase and catalase activity and expression in honey bee. Arch Insect Biochem Physiol 2015, 90:181-194.

30. DeGrandi-Hoffman G, Chen Y: Nutrition, immunity and viral infections in honey bees. Curr Opin Insect Sci 2015, 10:170-176.

31. Orcic S, Nikolic T, Purac J, Sikoparija B, Blagojević P D, Vukasinovic E, Plavsa N, Stevanovic J, Kojic D: Seasonal variations in the activity of selected antioxidant enzymes and malondialdehyde level in worker honey bees. Entomol Exp Appl 2017, 165:120-128.

32. Stanimirovic Z, Pejovic D, Stevanovic J, Vucinic M, Mirilovic M: Investigations of hygienic behaviour and disease resistance in organic beekeeping of two honeybee ecogeographic varieties from Serbia. Acta Vet-Beograd 2002, 52:169-180.

33. Stanimirovic Z, Stevanovic J, Cirkovic D: Behavioural defenses of the honey bee ecotype from Sjenica - Pester against Varroa destructor. Acta Vet-Beograd 2005a, 55:69-82.

34. Stanimirovic Z, Stevanovic J, Mirilovic M, Stojic V Heritability of hygienic behaviour in grey honey bees (Apis mellifera carnica). Acta Vet-Beograd 2008, 58:593-601. 
35. Stanimirovic Z, Stevanovic J, Aleksic N, Stojic V: Heritability of grooming behaviour in grey honey bees (Apis mellifera carnica). Acta Vet-Beograd 2010b; 60:313-323.

36. Stanimirović Z, Aleksic N, Stevanovic J, Cirkovic D, Mirilovic M, Djelic N, Stojic V: The influence of pulverised sugar dusting on the degree of infestation of honey bee colonies with Varroa destructor. Acta Vet-Beograd 2011, 61:309-325.

37. Stevanovic J: Ecological-ethological defence mechanisms of Apis mellifera carnica against ectoparasite Varroa destructor on the territory of Serbia, $\mathrm{PhD}$ dissertation, University of Belgrade, 2007.

38. Pejovic D: Investigation of the heritability of hygienic and grooming behaviour of grey honey bee Apis mellifera carnica and the influence of these features on reproductive and productive traits of honey bee colonies, PhD dissertation, University of Belgrade, 2008.

39. Cirkovic D: The investigation on the effects of pulverised sucrose on the degree of honeybee infestation with Varroa destructor, $\mathrm{PhD}$ dissertation, University of Belgrade, 2011.

40. Goblirsch M, Huang ZY, Spivak M: Physiological and behavioral changes in honey bees (Apis mellifera) induced by Nosema ceranae infection. PLoS ONE 2013, 8:e58165.

41. Stanimirovic Z, Fister S, Stevanovic J: Analysis of sister chromatid exchanges in cultured human lymphocytes treated with cymiazole hydrochloride. Acta Vet-Beograd 2003a, 53:419-425.

42. Stanimirovic Z, Todorovic D, Stevanovic J, Mladenovic M, Jankovic Lj, Djorđevic M: Influence of cymiazole hydrochloride on mitotic and proliferative activities of cultured human lymphocytes. Acta Vet-Beograd 2003b, 53:47-55.

43. Stanimirovic Z, Stevanovic J, Jovanovic S, Andjelkovic M: Evaluation of genotoxic effects of Apitol® (cymiazole hydrochloride) in vitro by measurement of sister chromatid exchange. Mutat Res-Gen Tox En 2005b, 588:152-157.

44. Stanimirovic Z, Stevanovic J, Bajic V, Radovic I: Evaluation of genotoxic effects of fumagillin by cytogenetic tests in vivo. Mutat Res-Gen Tox En 2007a, 628:1-10.

45. Stanimirovic Z, Pejin II, Kulisic Z, Djiporovic M: Evaluation of genotoxic effects of fumagillin by sister chromatide exchange and chromosomal aberration tests in human cell cultures. Acta Vet-Beograd 2007b, 57:257-273.

46. Pejin II, Stanimirović Z, Stevanović J, Kulišić Z: Evaluation of genotoxic potential of amitraz by cytogenetic test in vivo. Veterinarski glasnik 2006, 60:163-173.

47. Stevanovic J, Stanimirovic Z, Radakovic M, Stojic V: In vitro evaluation of the clastogenicity of fumagillin. Environ Mol Mutagen 2008, 49:594-601.

48. Radakovic M, Stevanovic J, Djelic N, Lakic N, Knezevic-Vukcevic J, Vukovic-Gacic B, Stanimirovic Z: Evaluation of the DNA damaging effects of amitraz on human lymphocytes in the Comet assay. J Biosciences 2013, 38:53-62.

49. Rosenkranz P, Aumeier P, Ziegelmann B: Biology and control of Varroa destructor. J Invertebr Pathol 2010, 103:S96-S119.

50. Genersch E: Honey bee pathology: current threats to honey bees and beekeeping. Appl Microbiol Biotechnol 2010, 87:87-97.

51. Genersch E, von der Ohe W, Kaatz H, Schroeder A, Otten C, Büchler R, Berg S, Ritter W, Mühlen W, Gisder S, Meixner M, Liebig G, Rosenkranz P: The German bee monitoring project: a long term study to understand periodically high winter losses of honey bee colonies. Apidologie 2010, 41:332-352. 
52. Genersch E, Aubert M: Emerging and re-emerging viruses of the honey bee (Apis mellifera L.).Vet Res 2010 41:54.

53. Guzmán-Novoa E, Eccles L, Calvete Y, Mcgowan J, Kelly PG, Correa-Benítez A: Varroa destructor is the main culprit for the death and reduced populations of overwintered honey bee (Apis mellifera) colonies in Ontario, Canada. Apidologie 2010, 41:443-450.

54. Ramsey SD, Ochoa R, Bauchan G, Gulbronson C, Mowery JD, Cohen A, Lim D, Joklika J, Cicero JM, Ellis JD, Hawthorne D, vanEngelsdorp D: Varroa destructor feeds primarily on honey bee fat body tissue and not hemolymph. P Natl Acad Sci USA 2019, 116:1792-1801.

55. Di Prisco G, Annoscia D, Margiotta M, Ferrara R, Varricchio P, Zanni V, Caprio E, Nazzi F, Pennacchio F: A mutualistic symbiosis between a parasitic mite and a pathogenic virus undermines honey bee immunity and health. P Natl Acad Sci USA, 2016, 113:3203-3208.

56. Zhao Y, Heerman M, Peng W, Evans JD, Rose R, DeGrandi-Hoffman G, Simone-Finstrom M, Li J, Li Z, Cook SC, Su S, Rodríguez-García C, Banmeke O, Hamilton M, Chen Y: The dynamics of deformed wing virus concentration and host defensive gene expression after Varroa mite parasitism in honey bees, Apis mellifera. Insects 2019, 10:16.

57. Alaux C, Dantec C., Parrinello H, Le Conte Y: Nutrigenomics in honey bees: digital gene expression analysis of pollen's nutritive effects on healthy and varroa-parasitized bees. BMC Genomics 2011, 12:496.

58. Shen M, Yang X, Cox-Foster D, Cui L: The role of varroa mites in infections of Kashmir bee virus (KBV) and deformed wing virus (DWV) in honey bees. Virology 2005a, 342:141149.

59. Shen M, Cui L, Ostiguy N, Cox-Foster D: Intricate transmission routes and interactions between picorna-like viruses (Kashmir bee virus and sacbrood virus) with the honeybee host and the parasitic varroa mite. J Gen Virol 2005b, 86:2281-2289.

60. Berényi O, Bakonyi T, Derakhshifar I, Köglberger H, Nowotny N: Occurrence of six honeybee viruses in diseased Austrian apiaries. Appl Environ Microbiol 2006, 72:24142420.

61. Martin SJ, Highfield AC, Brettell L, Villalobos EM, Budge GE, Powell M, Nikaido S, Schroeder DC: Global honey bee viral landscape altered by a parasitic mite. Science 2012, 336:1304-1306.

62. Nazzi F, Brown SP, Annoscia D, Del Piccolo F, Di Prisco G, Varricchio P, Della Vedova G, Cattonaro F, Caprio E, Pennacchio F: Synergistic parasite-pathogen interactions mediated by host immunity can drive the collapse of honeybee colonies. PLoS Pathog 2012, 8:e1002735.

63. Gregorc A, Evans JD, Scharf M, Ellis JD: Gene expression in honey bee (Apis mellifera) larvae exposed to pesticides and Varroa mites (Varroa destructor). J Insect Physiol 2012, 58:1042-1049.

64. Francis RM, Nielsen SL, Kryger P: Varroa-virus interaction in collapsing honey bee colonies. PLoS ONE, 2013, 8:e57540.

65. Sabin LR, Hanna SL, Cherry S: Innate antiviral immunity in Drosophila. Curr Opin Immunol 2010, 22:4-9.

66. Nazzi F, Pennacchio F: Disentangling multiple interactions in the hive ecosystem. Trends Parasitol 2014, 30:556-561.

67. Fine JD, Cox-Foster DL, Mullin CA: An inert pesticide adjuvant synergizes viral pathogenicity and mortality in honey bee larvae. Sci Rep-UK 2017, 7:40499. 
68. Simeunovic P, Stevanovic J, Vidanovic D, Nisavic J, Radovic D, Stanisic Lj, Stanimirovic Z: A survey of deformed wing virus and acute bee paralysis virus in honey bee colonies from Serbia using real-time RT-PCR. Acta Vet-Beograd 2014a, 64:81-92.

69. Cirkovic D, Stevanovic J, Glavinic U, Aleksic N, Djuric S, Aleksic J, Stanimirovic Z: Honey bee viruses in Serbian colonies of different strength. PeerJ 2018, 6:e5887.

70. Taric E, Glavinic U, Stevanovic J, Vejnovic B, Aleksic N, Dimitrijevic V, Stanimirovic Z: Occurrence of honey bee (Apis mellifera L.) pathogens in commercial and traditional hives. J Apicult Res 2019, DOI: 10.1080/00218839.2018.1554231.

71. Glavinic U, Stevanovic J, Gajic B, Simeunovic P, Đuric S, Vejnovic B, Stanimirovic Z: Nosema ceranae DNA in honey bee haemolymph and honey bee mite Varroa destructor. Acta Vet-Beograd 2014, 64:349-357.

72. Grozinger CM, Flenniken ML: Bee Viruses: Ecology, Pathogenicity, and Impacts. Annu Rev Entomol 2019, 64:205-226.

73. Stanimirović Z, Glavinic U, Lakic N, Radovic D, Ristanic M, Taric E, Stevanovic J: Efficacy of plant-derived formulation "Argus Ras" in Varroa destructor control. Acta Vet-Beograd 2017, 67:191-200.

74. Giacomelli A, Pietropaoli M, Carvelli A, Iacoponi F, Formato G: Combination of thymol treatment (Apiguard ${ }^{\circledR}$ ) and caging the queen technique to fight Varroa destructor. Apidologie 2016, 47:606-616.

75. Stanimirović Z, Ćirković D, Pejin II, Pejović D: Strategy for ecologic control in fighting Varroa destructor. Veterinarski glasnik 2007c, 61:11-35.

76. Stevanovic J, Stanimirovic Z, Lakic N, Aleksic N, Simeunovic P, Kulisic Z: Safety assessment of sugar dusting treatments by analysis of hygienic behavior in honey bee colonies. Arch Biol Sci 2011a, 63:1199-1207.

77. Stevanovic J, Stanimirovic Z, Lakic N, Djelic N, Radovic I: Stimulating effect of sugar dusting on honey bee grooming behaviour. Entomol Exp Appl 2012a, 143:23-30.

78. Lodesani M, Costa M: Limits of chemotherapy in beekeeping: development of resistance and the problem of residues. Bee World 2005, 86:102-109.

79. Loucif-Ayad W, Aribi N, Smagghe G, Soltani N: Comparative effectiveness of some acaricides used to control Varroa destructor (Mesostigmata: Varroidae) in Algeria. Afr Entomol 2010, 18:259-266.

80. Kanga LHB, Adamczyk J, Marshall K, Cox R: Monitoring for resistance to organophosphorus and pyrethroid insecticides in Varroa mite populations. J Econ Entomol 2010, 103:17971802.

81. Bogdanov S: Contaminants of bee products. Apidologie 2006, 37:1-18.

82. Adamczyk S, Lázaro R, Pérez-Arquillué C, Herrera A: Determination of synthetic acaricides residues in beeswax by high-performance liquid chromatography with photodiode array detector. Anal Chim Acta 2007, 581:95-101.

83. Adamczyk S, Lázaro R, Pérez-Arquillué C, Bayarri S, Herrera A: Impact of the use of fluvalinate on different types of beeswax from Spanish hives. Arch Environ Con Tox 2010, 58:733-739.

84. Stevanovic J, Stanimirovic Z, Aleksic N, Simeunovic P, Vucicevic M: The influence of natural and synthetic substances applied in honey bee health care on the quality of bee products (invited paper). Proceedings of the Apimondia Symposium "APIECOTECH SERBIA 2012“, Feb 18-19, 2012b, Belgrade, Serbia, pp 9-34. 
85. Bogdanov S, Kolchenmann V, Imdorf A: Acaricide residues in some bee products. J Apicult Res 1998, 37:57-67.

86. Chauzat MP, Faucon JP, Martel AC, Lachaize J, Cougoule N, Aubert M: A survey of pesticide residues in pollen loads collected by honey bees in France. J Econ Entomol 2006, 99:253-262.

87. Chauzat MP, Faucon JP: Pesticides residues in beeswax samples collected from honey-bee colonies (Apis mellifera) in France. Pest Manag Sci 2007, 63:1100-1106.

88. Frazier M, Mullin C, Frazier J, Ashcraft S: What have pesticides got to do with it? Am Bee J 2008, 148:521-523.

89. Mullin CA, Frazier M, Frazier JL, Ashcraft S, Simonds R, vanEngelsdorp D, Pettis JS: High levels of miticides and agrochemicals in North American apiaries: Implications for honey bee health. PLoS ONE 2010, 5:e9754.

90. Orantes-Bermejo FJ, Pajuelo AG, Megías MM, Fernández-Píñar C: Pesticide residues in beeswax and beebread samples collected from honey bee colonies (Apis mellifera L.) in Spain. Possible implications for bee losses. J Apicult Res 2010, 48:243-250.

91. Chauzat MP, Carpentier P, Martel AC, Bougeard S, Cougoule N, Porta P, Lachaize J, Madec F, Aubert M, Faucon JP: Influence of pesticide residues on honey bee (Hymenoptera: Apidae) colony health in France. Environ Entomol 2009, 38:514-523.

92. Bevk D, Kralj J, Čokl A: Coumaphos affects food transfer between workers of honeybee Apis mellifera. Apidologie 2012, 43:465-470.

93. Umpiérrez ML, Santos E, González A, Rossini C: Plant essential oils as potential control agents of varroatosis. Phytochem Rev 2011, 10:227-244.

94. Satta A, Floris I, Eguaras M, Cabras P, Garau VL, Melis M: Formic acid-based treatments for control of Varroa destructor in a Mediterranean area. J Econ Entomol 2005, 98:267-273.

95. Damiani N, Gende LB, Bailac P, Marcangeli JA, Eguaras MJ: Acaricidal and insecticidal activity of essential oils on Varroa destructor (Acari: Varroidae) and Apis mellifera (Hymenoptera: Apidae). Parasitol Res 2009, 106:145-152.

96. DeGrandi-Hoffman G, Ahumada F, Probasco G, Schantz, L: The effects of beta acids from hops (Humulus lupulus) on mortality of Varroa destructor (Acari: Varroidae). Exp Appl Acarol 2012, 58:407-421.

97. Ebert TA, Kevan PG, Bishop BL, Kevan SD, Downer RA: Oral toxicity of essential oils and organic acids fed to honey bees (Apis mellifera). J Apicult Res 2007, 46:220-224.

98. Ziegelmann B, Abele E, Hannus S, Beitzinger M, Berg S, Rosenkranz P: Lithium chloride effectively kills the honey bee parasite Varroa destructor by a systemic mode of action. Sci Rep-UK 2018, 8:683.

99. Forsgren E: European foulbrood in honey bees, J Invertebr Pathol 2010, 103:5-9.

100. Vojvodic S, Boomsma JJ, Eilenberg J, Jensen AB: Virulence of mixed fungal infections in honey bee brood. Front Zool 2012, 9:5.

101.Jensen AB, Aronstein K, Flores JM, Vojvodic S, Palacio MA, Spivak M: Standard methods for fungal brood disease research. In: Dietemann V, Ellis JD and Neumann P (Eds.) The COLOSS BEEBOOK, Volume II: Standard methods for Apis mellifera research. J Apicult Res 2013, 52 (1) DOI: 10.3896/IBRA.1.52.1.13

102. Ashiralieva A, Genersch E: Reclassification, genotypes and virulence of Paenibacillus larvae, the etiological agent of American foulbrood in honeybees - a review. Apidologie 2006, $37: 411-420$. 
103. Forsgren E, Stevanovic J, Fries I: Variability in germination and in temperature and storage resistance among Paenibacillus larvae genotype. Vet. Microbiol 2008, 129:342-349.

104.Forsgren E, Budge GE, Charrière JD, Hornitzky MA: Standard methods for European foulbrood research. In: Dietemann V, Ellis JD and Neumann P (Eds.) The COLOSS BEEBOOK, Volume II: Standard methods for Apis mellifera research. J Apicult Res 2013, 52 (1) DOI: 10.3896/IBRA.1.52.1.12

105. Wilkins S, Brown M, Andrew A, Cuthbertson GS: The incidence of honey bee pests and diseases in England and Wales. Pest Manag Sci 2007, 63:1062-1068.

106. Roetschi A, Berthoud H, Kuhn R, Imdorf A: Infection rate based on quantitative realtime PCR of Melissococcus plutonius, the causal agent of European foulbrood, in honeybee colonies before and after apiary sanitation. Apidologie 2008, 39:362-371.

107.Forsgren E, Lundhagen AC, Imdorf A, Fries I: Distribution of Melissococcus plutonius in honeybee colonies with and without symptoms of European foulbrood. Microbial Ecol 2005, 50:369-374.

108. Hedtke K, Jensen PM, Jensen AB, Genersch E: Evidence for emerging parasites and pathogens influencing outbreaks of stress-related diseases like chalkbrood. J Invertebr Pathol 2011, 108:167-173.

109. Aronstein K, Murray KD: Chalkbrood disease in honey bees. J Invertebr Pathol 2010, 103:S20-S29.

110.Stevanovic J, Stanimirovic Z, Genersch E, Kovacevic RS, Ljubenkovic J, Radakovic M, Aleksic N. Dominance of Nosema ceranae in honey bees in the Balkan countries in the absence of symptoms of colony collapse disorder. Apidologie 2011b, 41:49-58.

111. Stevanovic J, Simeunovic P, Gajic B, Lakic N, Radovic D, Fries I, Stanimirovic Z: Characteristics of Nosema ceranae infection in Serbian honey bee colonies. Apidologie 2013, 44:522-536.

112. Stevanovic J, Schwarz RS, Vejnovic B, Evans JD, Irwin RE, Glavinic U, Stanimirovic Z. Species-specific diagnostics of Apis mellifera trypanosomatids: a nine-year survey (20072015) for trypanosomatids and microsporidians in Serbian honey bees. J Invertebr Pathol 2016, 139:6-11.

113. Schwarz RS, Bauchan GR, Murphy C, Ravoet J, de Graaf DC, Evans JD: Characterization of two species of Trypanosomatidae from the honey bee Apis mellifera: Crithidia mellificae Langridge and McGhee, and Lotmaria passim. J Eukaryot Microbiol 2015a, 62:567-583.

114. Vejnovic B, Stevanovic J, Schwarz RS, Aleksic N, Mirilovic M, Jovanovic NM, Stanimirovic Z: Quantitative PCR assessment of Lotmaria passim in Apis mellifera colonies co-infected naturally with Nosema ceranae. J Invertebr Pathol 2018, 151:76-81.

115. Martín-Hernández, R, Botías, C, Bailón, E G, Martínez-Salvador, A, Prieto, L, Meana, A, Higes, M: Microsporidia infecting Apis mellifera: coexistence or competition. Is Nosema ceranae replacing Nosema apis?. Environ Microbiol 2012, 14:2127-2138.

116. Higes M, Meana A, Bartolomé C, Botías C, Martín-Hernández R: Nosema ceranae (Microsporidia), a controversial 21st century honey bee pathogen. Env Microbiol Rep 2013, 5:17-29.

117.Schwarz RS, Huang Q, Evans JD: Hologenome theory and the honey bee pathosphere. Curr Opin Insect Sci 2015b, 10:1-7.

118.Martín-Hernández, R., Bartolomé, C., Chejanovsky, N., Le Conte, Y., Dalmon, A., Dussaubat, C., García-Palencia, P., Meana, A., Pinto, M.A., Soroker, V. and Higes, M: Nosema ceranae in Apis mellifera: a 12 years postdetection perspective. Environ Microbiol 2018, 20:1302-1329. 
119. Fries I: Nosema ceranae in European honey bees (Apis mellifera). J Invertebr Pathol 2010, 103:S73-S79.

120. Gisder S, Hedtke K, Möckel N, Frielitz MC, Linde A, Genersch E: Five-year cohort study of Nosema spp. in Germany: does climate shape virulence and assertiveness of Nosema ceranae? Appl Environ Microb 2010, 76:3032-3038.

121. Gisder S, Schüler V, Horchler LL, Groth D, Genersch E: Long-term temporal trends of Nosema spp. infection prevalence in Northeast Germany: Continuous spread of N. ceranae, an emerging pathogen of honey bees (Apis mellifera), but no general replacement of $N$. apis. Front Cell Infect Microbiol 2017, 7:301.

122.Forsgren E, Fries I: Temporal study of Nosema spp. in a cold climate. Environ Microbiol Rep 2013, 5:78-82.

123. Chemurot M, De Smet L, Brunain M, De Rycke R, de Graaf DC: Nosema neumanni n. sp. (Microsporidia, Nosematidae), a new microsporidian parasite of honeybees, Apis mellifera in Uganda. Eur J Protistol 2017, 61:13-19.

124.Martín-Hernández R, Meana A, Prieto L, Salvador AM, Garrido-Bailón E, Higes M. Outcome of colonization of Apis mellifera by Nosema ceranae, Appl Environ Microb 2007, 73:6331-6338.

125.Higes M, Martín-Hernández R, Botías C, Garrido Bailón E, González-Porto AV, Barrios L, Del Nozal MJ, Bernal JL, Jiménez JJ, Palencia PG, Meana A: How natural infection by Nosema ceranae causes honeybee colony collapse. Environ Microbiol 2008, 10:2659-2669.

126. Higes M, Martín-Hernández R, Garrido-Bailón E, González-Porto AV, García-Palencia P, Meana A, Del Nozal MJ, Mayo R, Bernal JL: Honeybee colony collapse due to Nosema ceranae in professional apiaries. Env Microbiol Rep 2009, 1:110-113.

127. Antúnez K, Martín-Hernández R, Prieto L, Meana A, Zunino P, Higes M: Immune suppression in the honey bee (Apis mellifera) following infection by Nosema ceranae (Microsporidia). Environ Microbiol 2009, 11:2284-2290.

128. Chaimanee V, Chantawannakul P, Chen Y, Evans YD, Pettis JS: Differential expression of immune genes of adult honey bee (Apis mellifera) after inoculated by Nosema ceranae. J Insect Physiol 2012, 58:1090-1095.

129. Glavinic U, Stankovic B, Draskovic V, Stevanovic J, Petrovic T, Lakic N, Stanimirovic Z: Dietary amino acid and vitamin complex protects honey bee from immunosuppression caused by Nosema ceranae. PLoS ONE 2017, 12:e0187726.

130. Higes M, Martin-Hernandez R, Meana A: Nosema ceranae in Europe: an emergent type C nosemosis. Apidologie 2010, 41:375-392.

131. Simeunovic P, Stevanovic J, Cirkovic D, Radojicic S, Lakic N, Stanisic L, Stanimirovic Z: Nosema ceranae and queen age influence the reproduction and productivity of the honey bee colony. J Apicult Res 2014b, 53:545-554.

132. Bacandritsos N, Granato A, Budge G, Papanastasiou I, Roinioti E, Caldon M, Falcaro C, Gallina A, Mutinelli F: Sudden deaths and colony population decline in Greek honey bee colonies. J Invertebr Pathol 2010, 105:335-340.

133. Bromenshenk JJ, Henderson CB, Wick CH, Stanford MF, Zulich AW, Jabbour RE, Deshpande SV, McCubbin PE, Seccomb RA, Welch PM, Williams T: Iridovirus and microsporidian linked to honey bee colony decline. PLoS ONE 2010, 5:e13181.

134. Soroker V, Hetzroni A, Yakobson B, David D, David A, Voet H, Slabezki Y, Efrat H, Levski S, Kamer Y, Klinberg E, Zioni N, Inbar S, Chejanovsky N: Evaluation of colony losses in Israel in relation to the incidence of pathogens and pests. Apidologie, 2011, 42:192-199. 
135. Vidau C, Diogon M, Aufauvre J, Fontbonne R, Viguès B, Brunet JL, Texier C, Biron DG, Blot N, Al Alaoui H, Belzunces LP, Delbac F: Exposure to sublethal doses of fipronil and thiacloprid highly increases mortality of honeybees previously infected by Nosema ceranae. PLoS ONE 2011, 6:e21550.

136. Aufauvre J, Biron DG, Vidau C, Fontbonne R, Roudel M, Diogon M, Viguès B, Belzunces LP, Delbac F, Blot N: Parasite-insecticide interactions: a case study of Nosema ceranae and fipronil synergy on honeybee. Sci Rep-UK 2012, 2:326.

137. Aufauvre J, Misme-Aucouturier B, Viguès B, Texier C, Delbac F, Blot N: Transcriptome analyses of the honeybee response to Nosema ceranae and insecticides. PLoS ONE 2014, 9:e91686.

138. Glavinic U, Tesovnik T, Stevanovic J, Zorc M, Cizelj I, Stanimirovic Z, Narat M: Response of adult honey bees treated in larval stage with prochloraz to infection with Nosema ceranae. PeerJ 2019,7:e6325

139. Retschnig G, Neumann P, Williams GR: Thiacloprid-Nosema ceranae interactions in honey bees: Host survivorship but not parasite reproduction is dependent on pesticide dose. J Invertebr Pathol 2014, 118:18-19.

140. Blacquiere T, Smagghe G, van Gestel CAM, Mommaerts V: Neonicotinoids in bees: A review on concentrations, side-effects and risk assessment. Ecotoxicology 2012, 21:973992.

141. Van der Sluijs JP, Simon-Delso N, Goulson D, Maxim L, Bonmatin JM, Belzunces LP: Neonicotinoids, bee disorders and the sustainability of pollinator services. Curr Opin Env Sust 2013, 5:293-305.

142. Abbo PM, Kawasaki JK, Hamilton M, Cook SC, DeGrandi-Hoffman G, Li WF, Liu J, Chen YP: Effects of imidacloprid and Varroa destructor on survival and health of European honey bees, Apis mellifera. Insect Sci 2017, 24:467-477.

143. Tison L, Hahn ML, Holtz S, Rößner A, Greggers U, Bischoff G, Menzel R: Honey bees' behavior is impaired by chronic exposure to the neonicotinoid thiacloprid in the field. Environ Sci Technol 2016, 50:7218-7227.

144.Straub L, Villamar-Bouza L, Bruckner S, Chantawannakul P, Gauthier L, Khongphinitbunjong K, Retschnig G, Troxler A, Vidondo B, Neumann P, Williams GR: Neonicotinoid insecticides can serve as inadvertent insect contraceptives. Proc R Soc B 2016, 283:20160506.

145.Di Prisco G, Cavaliere V, Annoscia D, Varricchio P, Caprio E, Nazzi F, Gargiulo G, Pennacchio F: Neonicotinoid clothianidin adversely affects insect immunity and promotes replication of a viral pathogen in honey bees. P Natl Acad Sci USA, 2013, 110:1846618471.

146.Brandt A, Gorenflo A, Siede R, Meixner M, Büchler R: The neonicotinoids thiacloprid, imidacloprid, and clothianidin affect the immunocompetence of honey bees (Apis mellifera L.). J Insect Physiol 2016, 86:40-47.

147. Thompson HM, Fryday SL, Harkin S, Milner S: Potential impacts of synergism in honeybees (Apis mellifera) of exposure to neonicotinoids and sprayed fungicides in crops. Apidologie 2014, 45:545-553.

148. Sgolastra F, Medrzycki P, Bortolotti L, Renzi MT, Tosi S, Bogo G, Teper D, Porrini C, Molowny-Horas R, Bosch J: Synergistic mortality between a neonicotinoid insecticide and an ergosterol-biosynthesis-inhibiting fungicide in three bee species. Pest Manag Sci 2017, 73:1236-1243. 
149.Johnson RM, Dahlgren L, Siegfried BD, Ellis MD: Acaricide, fungicide and drug interactions in honey bees (Apis mellifera). PLoS ONE 2013, 8:e54092.

150.Lambert O, Piroux M, Puyo S, Thorin C, L'Hostis M, Wiest L, Bulete A, Delbac F, Pouliquen $\mathrm{H}$ : Widespread occurrence of chemical residues in beehive matrices from apiaries located in different landscapes of Western France. PLoS ONE 2013, 8:e67007.

151.Cizelj I, Glavan G, Božič J, Oven I, Mrak V, Narat M: Prochloraz and coumaphos induce different gene expression patterns in three developmental stages of the Carniolan honey bee (Apis mellifera carnica Pollmann). Pestic Biochem Phys 2016, 128:68-75.

152. Seeley T, Tarpy D: Queen promiscuity lowers disease within honeybee colonies. Proc R Soc London Sci - Ser B 2007, 274:67-72.

153.Higes M, Nozal MJ; Alvaro A, Barrios L, Meana A, Martín-Hernández R, Bernal LJ, Bernal $\mathrm{J}$ : The stability and effectiveness of fumagillin in controlling Nosema ceranae (Microsporidia) infection in honey bees (Apis mellifera) under laboratory and field conditions. Apidologie 2011, 42:364-377.

154. Van den Heever JP, Thompson TS, Otto SJ, Curtis JM, Ibrahim A, Pernal SF: Evaluation of Fumagilin- $\mathrm{B} \mathbb{R}$ and other potential alternative chemotherapies against Nosema ceranaeinfected honeybees (Apis mellifera) in cage trial assays. Apidologie 2016a, 47:617-630.

155. Van den Heever JP, Thompson TS, Otto SJ, Curtis JM, Ibrahim A, Pernal SF: The effect of dicyclohexylamine and fumagillin on Nosema ceranae-infected honey bee (Apis mellifera) mortality in cage trial assays. Apidologie 2016b, 47:663-670.

156. van den HeeverJP, Thompson TS, Curtis JM, PernalSF: Determination of dicyclohexylamine and fumagillin in honey by LC-MS/MS. Food Anal Method 2015a, 8:767-777.

157.van den Heever JP, Thompson TS, Curtis JM, Pernal SF: Stability of dicyclohexylamine and fumagillin in honey. Food Chem 2015b, 179:152-158.

158. Runckel C, Flenniken ML, Engel JC, Ruby JG, Ganem D, Andino R, DeRisi JL: Temporal analysis of the honey bee microbiome reveals four novel viruses and seasonal prevalence of known viruses, Nosema, and Crithidia. PLoS ONE 2011, 6:e20656.

159. Cornman RS, Tarpy DR, Chen Y, Jeffreys L, Lopez D, Pettis JS, Evans JD: Pathogen webs in collapsing honey bee colonies. PLoS ONE 2012, 7:e43562.

160. Ravoet J, Maharramov J, Meeus I, De Smet L, Wenseleers T, Smagghe G, De Graaf DC: Comprehensive bee pathogen screening in Belgium reveals Critbidia mellificae as a new contributory factor to winter mortality. PLoS ONE 2013, 8:e72443.

161. Ravoet J, Schwarz RS, Descamp T, Yanez O, Tozkar O, Martin-Hernandez R, De Smet L, DeRisi J, Higes M, Wenseleers T, Schmid-Hempel R, Neumann P, Kadowaki T, Evans JD, de Graaf DC: Differential diagnosis of the honey bee trypanosomatids Crithidia mellificae and Lotmaria passim. J Invertebr Pathol 2015, 130:21-27.

162. Schwarz RS, Evans JD: Single and mixed-species trypanosome and microsporidia infections elicit distinct, ephemeral cellular and humoral immune responses in honeybees. Dev Comp Immunol 2013, 40:300-310.

163. Stevanovic J, Vejnovic B, Schwarz R, Aleksic N, Jovanovic N, Stanimirovic Z: Identification and quantification of Lotmaria passim (Trypanosomatidae) in investigation of its prevalence, annual dynamics and relationship with Nosema ceranae (Microsporidia). Book of plenary lectures, XXX Congresso SoIPA: Mutamenti Ambientali e Parassiti, June 26-29, 2018a, Milano, Italy pp. 55-57.

164. Radaković M, Vejnović B, Glavinić U, Aleksić N, Mirilović M, Stanimirović Z, Stevanović J: Oxidative stress increases in honey bees infected with Lotmaria passim. Abstract Book, 8th Congress of Apidology (EURBEE 8), Sept 18-20, 2018, pp. 108, Ghent, Belgium. 
165. Aleksic N, Stanimirovic Z, Stevanovic J: External contaminants of honey bee products (invited paper). In Zivadinovic, R. (Ed), Proceedings of the Apimondia Symposium "APIECOTECH SERBIA 2012“, Feb 18-19, 2012, Belgrade, Serbia, pp 46-63.

166. Calatayud-Vernich P, Calatayud F, Simó E, Picó Y: Pesticide residues in honey bees, pollen and beeswax: Assessing beehive exposure. Environmental Pollution 2018, 241:106-114.

167. Esteves RJP, Villadelrey MC, Rabajante JF: Determining the optimal distribution of bee colony locations to avoid overpopulation using mixed integer programming. Journal of Nature Studies 2010, 9:79-82.

168. Favre D: Mobile phone-induced honeybee worker piping. Apidologie 2011, 42:270-279.

169. Favre D: Disturbing honeybees' behavior with electromagnetic waves: a methodology. J Behav 2017, 2:1010.

170.Barron AB: Death of the bee hive: understanding the failure of an insect society. Curr Opin Insect Sci 2015, 10:45-50.

171. Archer CR, Köhler A, Pirk CW, Oosthuizen V, Apostolides Z, Nicolson SW: Antioxidant supplementation can reduce the survival costs of excess amino acid intake in honeybees. J Insect Physiol 2014, 71:78-86.

172.Farjan M, Lopieńska-Biernat E, Lipiński Z, Dmitryjuk M, Żółtowska K: Supplementing with vitamin $\mathrm{C}$ the diet of honeybees (Apis mellifera carnica) parasitized with Varroa destructor. effects on antioxidative status. Parasitology 2014, 141:770-776.

173.Ptaszyńska AA, Borsuk G, Zdybicka-Barabas A, Cytryńska M, Małek W: Are commercial probiotics and prebiotics effective in the treatment and prevention of honeybee nosemosis C?. Parasitol Res 2016, 115:397-406.

174. Stevanovic J, Stanimirovic Z, Simeunovic P, Lakic N, Radovic I, Sokovic M, Van Griensven JLD: The effect of Agaricus brasiliensis extract supplementation on honey bee colonies. An Acad Bras Cienc 2018b, 90:219-229.

175. Amiri E, Strand M, Rueppell O, Tarpy D: Queen quality and the impact of honey bee diseases on queen health: potential for interactions between two major threats to colony health. Insects 2017, 8:48.

176. Evans JD, Lopez DL: Bacterial probiotics induce an immune response in the honey bee (Hymenoptera: Apidae). J Econ Entomol 2004, 97:752-756.

177. Chan QW, Melathopoulos AP, Pernal SF, Foster LJ: The innate immune and systemic response in honey bees to a bacterial pathogen, Paenibacillus larvae. BMC Genomics 2009, 10:387.

178. Azzami K, Ritter W, Tautz J, Beier H: Infection of honey bees with acute bee paralysis virus does not trigger humoral or cellular immune responses. Arch Virol 2012, 157:689-702.

179. Gätschenberger H, Azzami K, Tautz J, Beier H: Antibacterial immune competence of honey bees (Apis mellifera) is adapted to different life stages and environmental risks. PLoS ONE 2013, 8:e66415. 


\title{
U POTRAZI ZA UZROCIMA I REŠENJIMA PROBLEMA GUBITAKA PČELINJIH DRUŠTAVA
}

\author{
STANIMIROVIĆ Zoran, GLAVINIĆ Uroš, RISTANIĆ Marko, ALEKSIĆ Nevenka, \\ JOVANOVIĆ Nemanja, VEJNOVIĆ Branislav, STEVANOVIĆ Jevrosima
}

Gubici pčelinjih društava, uključujući one izazvane sindromom CCD, predstavljaju urgentan problem savremenog pčelarenja koji privlači pažnju kako pčelara, tako i naučne javnosti. CCD se karakteriše odsustvom odraslih pčela u košnici u kojoj ostaje malo radilica sa maticom, veoma narušenim odnosom između količine legla i broja radilica u korist legla, uz prisustvo više nego dovoljno hrane. Grabež i štetočine koje obično napadaju oslabljena društva izostaju. U ovom radu prodiskutovani su uzroci gubitaka pčela, kao i mere prevencije. Analizirani su sledeći faktori koji dovode do gubitaka društava: nedostatak visokokvalitetne hrane (polena i meda); infestacija parazitima, naročito vrstom Varroa destructor, i mešovite virusne infekcije; bakterijske infekcije (američka i evropska trulež pčelinjeg legla), gljivične infekcije (nozemoza i askosferoza) i infekcije tripanozomama (lotmarioza); i, najzad, generalni manadžment na pčelinjaku. Preporučene su određene preventivne mere: (1) obezbeđivanje visokokvalitetne paše i čiste vode, (2) izbegavanje ,šećerizacije“, tj. preterane primene šećernog sirupa, (3) zadovoljenje nutritivnih potreba društva, (4) kod prihranjivanje pčela, treba voditi računa o vremenu davanja prihrane i njenom sastavu, izbegavati čist šećerni sirup koji u preteranim količinama može da dovede do energetskog i oksidativnog stresa, (5) kada postoji nedostatak prirodne hrane - u medištu i plodištu - koristiti šećerni sirup sa prirodnim/veštačkim suplementima da bi se izbegla proteinska glad, (6) organizovana kontrola $V$. destructor u društvima je obavezna zbog vektorske uloge krpelja, i (7) neophodno je pridržavati se higijenskih i sanitarnih mera i principa dobre pčelarske prakse i menadžmenta na pčelinjaku. Da zaključimo, sve preventivne mere se izvode u skladu sa zakonskom regulativom koja se odnosi na redovnu prolećnu i jesenju kontrolu zdravlja pčela. Sve kontrole treba da obavljaju licencirani doktori veterinarske medicine i predlože adekvatne tretmane ukoliko je to neophodno. 